\title{
Topography and post-fire climatic conditions shape spatio-temporal patterns of conifer establishment and growth
}

\author{
Caitlin E. Littlefield(D)
}

\begin{abstract}
Background: Concern is mounting that larger, stand-replacing forest fires may accelerate compositional shifts or conversions to non-forested states under a warming climate. Post-fire climatic conditions influence system trajectories by facilitating or hindering juvenile recruitment. But without an accurate, long-term understanding of where, when, and how climatic variability and other ecological factors affect regeneration, our ability to predict post-fire trajectories is limited. I quantified multiple, interacting facets of post-fire conifer regeneration-including annual establishment rates and growth-one decade after stand-replacing fire on the eastern slopes of the North Cascades, Washington, USA. Sites were stratified across topographic settings to specifically capture the potential for topography to moderate seasonal and interannual climatic conditions.

Results: Recruitment of juvenile conifers occurred every year since fire, with considerable species-specific variability across topographic settings and distance to seed source. Juveniles of all species, except lodgepole pine (Pinus contorta var. latifolia Engelm. ex S. Watson), were rarely observed when live, conspecific seed source was more than $75 \mathrm{~m}$ away. Lodgepole pine was the only species for which greater distance to live seed source was not associated with lower densities, a pattern attributable to serotiny. Annual establishment rates were strongly correlated with post-fire conditions: rates were highest when growing seasons were relatively cool and moist. A lagged climate signal was apparent in annual growth rates, but standardized climate-growth relationships did not vary across topographic settings, suggesting that topographic setting did not decouple site conditions from broader climatic trends to a degree that affected growth patterns.

Conclusions: These results underscore the importance of favorable post-fire climatic conditions in promoting robust establishment and growth while also highlighting the importance of topography and endogenous, stand-level processes (e.g., seed availability and delivery) in shaping recovery over time. Furthermore, these results suggest that, while the growing concern of post-fire regeneration failure may indeed be warranted under some conditions, failure is not yet the rule in all places and at all times. A more detailed understanding of recovery dynamics through long-term monitoring and by examining multiple, interacting facets of regeneration across scales will improve our predictions of where and when regeneration failure or, conversely, robust recovery may occur under a changing climate.
\end{abstract}

Keywords: climate-growth relationships, post-fire recovery, seed source, topoclimate, Western conifers 


\section{Resumen}

Antecedentes: Existe una preocupación creciente de que grandes incendios forestales que causan el reemplazo de rodales, puedan acelerar cambios en la composición o reconversiones a estados sin bosque bajo la influencia del calentamiento global. Las condiciones climáticas post-fuego influencian las trayectorias de los sistemas facilitando o dificultando el reclutamiento juvenil. Pero sin un entendimiento preciso y de largo plazo sobre el dónde, el cuándo y el como la variabilidad climática y otros factores ecológicos que afectan la regeneración, nuestra habilidad para predecir las trayectorias post-fuego son limitadas. He cuantificado múltiples facetas interactuantes de regeneración post-fuego de coníferas-incluyendo tasas de establecimiento anual y crecimiento-una década después de que un rodal fuera reemplazado por un fuego en las laderas este de las Cascadas del Norte, Washington, EEUU. Los sitios fueron estratificados a través de distintas posiciones topográficas para capturar específicamente el potencial de la topografía para moderar las condiciones climáticas estacionales e interanuales.

Resultados: El reclutamiento de coníferas juveniles ocurrió todos los años luego del fuego, con una considerable variabilidad específica de especies a lo largo de distintas posiciones topográficas y distancia a las fuentes de semillas. Juveniles de todas las especies salvo pino contorta (Pinus contorta var. latifolia Engelm. ex S. Watson), fueron raramente observadas cuando la fuente de semilla viva de la misma especie se encontró a más de $75 \mathrm{~m}$ de distancia. El pino contorta fue la única especie para la cual una mayor distancia a una fuente viva de semilla no fue asociada a menor densidad, un patrón atribuible a la serotinidad. Las tasas de establecimiento anual estuvieron fuertemente correlacionadas con condiciones post-fuego: las tasas fueron más altas cuando las estaciones de crecimiento fueron relativamente frescas y húmedas. Una señal de retraso climático fue aparente en tasas anuales de crecimiento, pero relaciones estandarizadas de clima y crecimiento no variaron a través de las condiciones topográficas, sugiriendo que dichas condiciones no se han desacoplado de las condiciones de sitio de tendencias climáticas más amplias a un grado tal que haya afectado los patrones de crecimiento.

Conclusiones: Estos resultados destacan la importancia de las condiciones climáticas post-fuego favorables en promover un establecimiento y crecimiento robusto, mientras que también realza la importancia de la topografía y de los procesos endógenos a nivel de rodal (por ej., disponibilidad y provisión de semillas) en dar forma a la recuperación a través del tiempo. Además, estos resultados sugieren que, mientras que la preocupación creciente de las fallas en la regeneración post-fuego pueden asegurarse bajo algunas condiciones, la falla no es la regla en todos los lugares y tiempos. Un comprensión detallada de la dinámica de la recuperación a través del monitoreo a largo plazo, y examinando las facetas múltiples e interactuantes de la regeneración a lo largo de las escalas, mejorarán nuestras predicciones de donde y cuando la regeneración fallará o, a la inversa, una recuperación robusta puede ocurrir en un clima cambiante.

\section{Background}

Concern is mounting that larger, stand-replacing forest disturbances may cause or accelerate species compositional shifts or conversions to non-forested states, with an accompanying decline in ecosystem services (Millar and Stephenson 2015; Seidl et al. 2016). Evidence from multiple forest systems in the western US suggests that climatic conditions play an important role in determining post-disturbance trajectories. Specifically, research has shown that droughty conditions can constrain regeneration, particularly in moisture-limited settings (Harvey et al. 2016; Tepley et al. 2017; Haffey et al. 2018; Kemp et al. 2019).

Recovery is predicated on the successful recruitment and survival of juveniles, which may be a more sensitive indicator of long-term system trajectories under climate change than adult trees (Germino et al. 2002; Jackson et al. 2009). Juveniles tend to have different environmental sensitivities than conspecific adults (Grubb 1977), including narrower climatic tolerances (Bell et al. 2014;
Dobrowski et al. 2015) and greater susceptibility to drought-induced mortality, frost damage, and photoinhibition, among other stressors (Germino et al. 2002; McDowell et al. 2008; Walck et al. 2011). As such, the juvenile life stage is a particularly important bottleneck to forest recovery.

Given its importance, researchers have sought to document patterns of post-fire regeneration across multiple forest types, with varying spatial and temporal lenses. Most research underscores the importance of adequate seed supply and seed delivery into burned patches (Donato et al. 2009; Harvey et al. 2016; Kemp et al. 2016). Research also documents how recovery varies along environmental gradients: frequently, more robust recovery occurs in cooler and moister topographic settings, whereas arid locations experience less recovery (Dodson and Root 2013; Harvey et al. 2016; Tepley et al. 2017). Some studies find minimal association between post-disturbance regeneration and simple topographic metrics (e.g., elevation) but find strong associations with 
finer-scaled variability in soil properties related to moisture availability (Donato et al. 2009; Redmond et al. 2015). This research suggests that fine-scaled variability in environmental conditions-even within the same fire or study area-can lead to high degrees of localized spatial variability in recovery.

These varied results highlight the need for considering, simultaneously, how multiple facets of topography at multiple scales shape the climatic conditions experienced by juvenile trees at any given site. These climatic conditions are an integration of broader macroclimate (e.g., atmospheric circulation patterns, on the order of $\geq 100 \mathrm{~km}$ ), regional mesoclimate (e.g., orographic effects, 1 to $100 \mathrm{~km})$, topoclimate $(0.01$ to $1 \mathrm{~km})$, and microclimate ( $<10 \mathrm{~m}$; Geiger et al. 2009). Microclimate is influenced by fine-scale surface features and vegetation cover and can strongly affect juvenile establishment (Germino et al. 2002; von Arx et al. 2013). Topoclimate describes the interaction of elevation, aspect, slope, and terrain in mediating how broader-scale climatic conditions are experienced on the ground (e.g., via heat loading or cold-air pooling), with strong implications for fine-scaled variability in moisture balance. Understanding where and when topoclimate plays a role in structuring post-fire regeneration can suggest a natural template for recovery-promoting management interventions (Hessburg et al. 2015).

Much existing research documents species presence and abundance and is often-although not always-conducted within several years of a fire. Research that captures juvenile establishment rates at an annual resolution for multiple years or decades since fire and links establishment rates to climatic variability is not prevalent in the literature but is a growing area of inquiry (e.g., Harvey et al. 2016; Rother and Veblen 2017; Urza and Sibold 2017; Stevens-Rumann et al. 2018; Davis et al. 2019). Data on annual height growth are even rarer (but see Tepley et al. 2017). Collectively examining these multiple facets of post-fire regeneration and their interactions at longer time scales offers a more robust picture of system resilience and may foretell disturbance-catalyzed shifts (Reyer et al. 2015; Donato et al. 2016).

In this research, I examined multiple dimensions of post-fire regeneration over 10 years since standreplacing fire across a broad range of topographic settings. Fire effects on these mixed conifer forests on the eastern slopes of the North Cascades, Washington, USA, have been documented (e.g., Lyons-Tinsley and Peterson 2012; Prichard and Kennedy 2014), but relatively little work has been done to specifically track post-fire regeneration (but see Cansler et al. 2018). I had three questions that guided this research: first, what are the spatial and temporal patterns of juvenile conifer establishment in this topographically complex landscape? Second, does topographic setting constrain species presence and annual establishment rates or do other limiting factors (e.g., seed source) predominate? Finally, does the relationship between the annual growth of juveniles and broader climatic conditions vary across the landscape? For example, are some topographic settings serving as refugia that buffer juveniles from broader climatic variability such that growth sensitivity to this variability is reduced? This work builds upon and differs from previous post-fire recovery research by examining multiple facets of juvenile regeneration-including annual growth-by directly linking these recovery dynamics to climatic variability across a range of topographic settings.

\section{Methods \\ Study area and site selection}

The study area lies within the 2006 Tripod Complex Fire perimeter (hereafter, Tripod Fire). The Tripod Fire burned 70750 hectares from 700 to $2400 \mathrm{~m}$ in elevation in the Okanogan-Wenatchee National Forest, northwest of Winthrop, Washington, USA (Fig. 1). Mean annual temperature was $5.65{ }^{\circ} \mathrm{C}$, with $-3.35{ }^{\circ} \mathrm{C}$ as the mean temperature of the coldest month (January), and $16.30{ }^{\circ} \mathrm{C}$ as the mean temperature of the warmest month (July). ${ }^{1}$ Mean annual precipitation was 392 $\mathrm{mm}$, much of which was snow and only $10 \%$ of which fell in July, August, and September. Conditions immediately following the Tripod Fire were cooler and slightly moister than these averages: annual temperature for the first five years post fire departed from the average by -0.31 units of standard deviation, and by -0.20 units for the first ten years. Annual precipitation for the first five years post fire departed from the average by 0.04 units of standard deviation, and by 0.1 units for the first ten years. ${ }^{2}$ Topography within the study area was highly complex, with steep slopes and numerous drainages dissecting the landscape, which contributed to a diversity of localized topoclimatic conditions.

At lower elevations, ponderosa pine (Pinus ponderosa var. ponderosa Douglas ex P. Lawson \& C. Lawson) and Douglas-fir (Pseudotsuga menziesii var. glauca [Mayr] Franco) woodlands historically supported low-severity, high-frequency fires, but stand densities and surface-fuel accumulation in many locations have increased considerably in the past century due to fire exclusion and the

\footnotetext{
${ }^{1}$ Data (1986 to 2016 averages) are from the Global Historical Climatology Network Station First Butte (ID: USR0000WFIR), at $48.6172^{\circ} \mathrm{N}, 120.1075^{\circ} \mathrm{W}$ and $1676 \mathrm{~m}$ in elevation, immediately west of the Tripod Fire perimeter. Data are available at https://www.ncdc. noaa.gov/cdo-web

${ }^{2}$ Annual z-scores for the post-fire period were computed relative to a 1986 to 2005 baseline.
} 


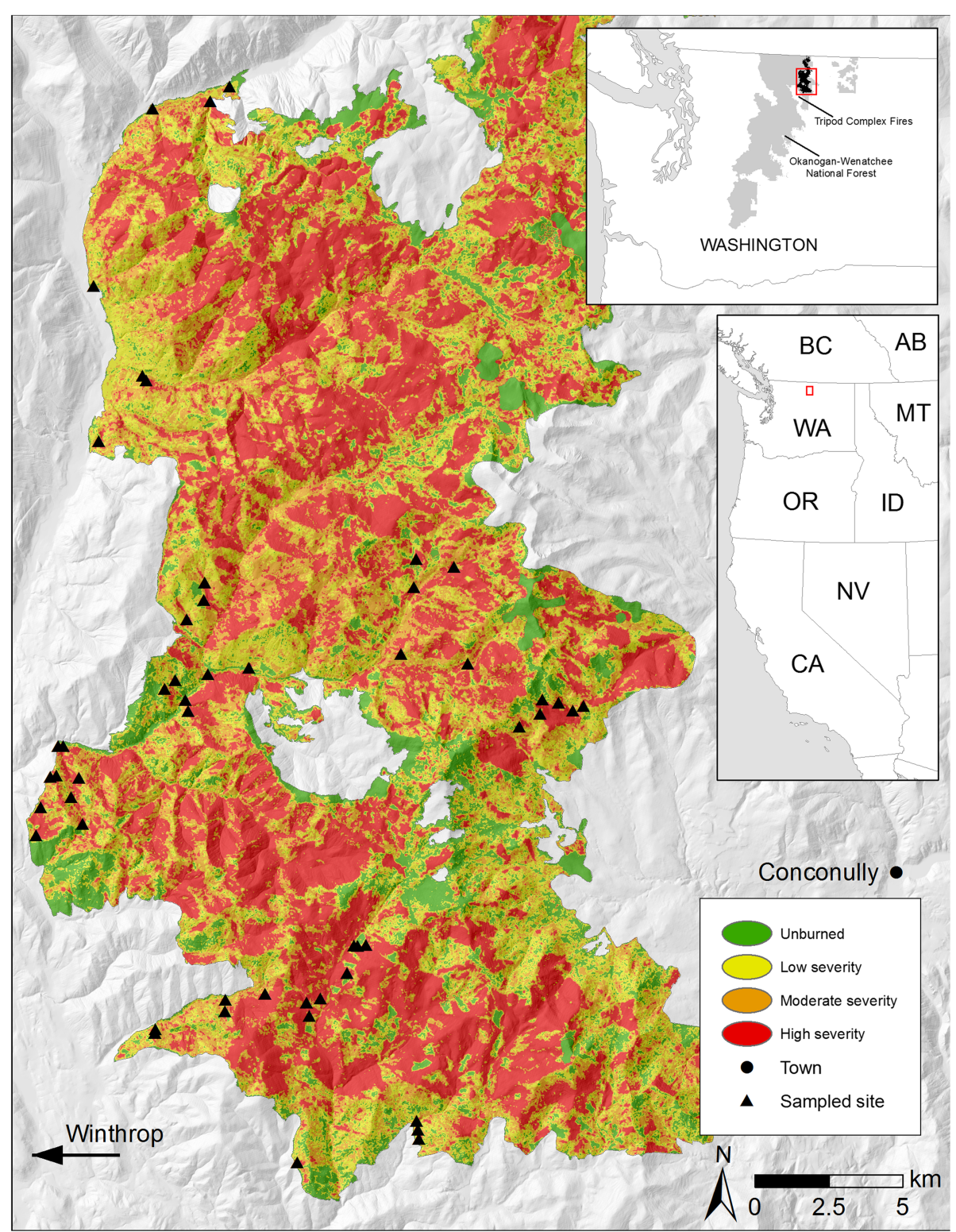

Fig. 1 Map of the Tripod Complex study area within the Okanogan-Wenatchee National Forest, Washington, USA. The towns of Conconully and Winthrop are indicated for reference. Canadian provinces in the inset map include British Columbia (BC) and Alberta (AB); USA states include Washington (WA), Idaho (ID), Montana (MT), California (CA), and NV (Nevada). Field data was collected in 2016

cessation of aboriginal burning (Hessburg et al. 2005). The mixed conifer montane forests (1000 to $1500 \mathrm{~m}$ ) are largely composed of ponderosa pine, Douglas-fir, lodgepole pine (Pinus contorta var. latifolia Engelm. ex S. Watson), and western larch (Larix occidentalis Nutt.), with smaller components of Engelmann spruce (Picea engelmannii Parry ex Engelm.) and subalpine fir (Abies lasiocarpa var. lasiocarpa [Hook.] Nutt.) that are more prevalent at higher elevations $(>1500 \mathrm{~m})$. The montane forests have historically supported mixed-severity fires, whereas higher elevations have a high-severity fire regime (Agee 1993). Juvenile conifers that recruit after fire in these mixed conifer forests are the population of inference in this study.

To capture the breadth of topoclimatic conditions in the study area while avoiding geographic bias, I randomly located sites across topographic settings based on strata of elevation, topographic wetness index (TWI), and heat load index (HLI; Table 1). Values of elevation, TWI, and HLI within the study area were binned into high, medium, and low strata (equal area) for each metric, and candidate sites were randomly and evenly 
Table 1 Topographic variables used in site selection for 2016 sampling on the Tripod Complex fires in the Okanogan-Wenatchee National Forest, Washington, USA, and as candidate predictor variables. All variables were computed at $100 \mathrm{~m}$ resolution from a digital elevation model (DEM)

\begin{tabular}{|c|c|c|c|c|}
\hline \multirow[b]{2}{*}{ Variable } & \multirow[b]{2}{*}{ Description and units } & \multirow[b]{2}{*}{ Source } & \multicolumn{2}{|c|}{ Tripod Fire data range } \\
\hline & & & Range & Mean \\
\hline Elevation & Elevation above sea level in meters & $\begin{array}{l}\text { National Elevation Dataset } \\
\text { (http://nationalmap.usgs.gov) }\end{array}$ & 697 to $2426^{1}$ & 1722 \\
\hline Slope & Slope angle in degrees & $\begin{array}{l}\text { Computed from DEM with ArcGIS v10.4 } \\
\text { Spatial Analyst (ESRI, Redlands, } \\
\text { California, USA.) }\end{array}$ & 0 to 48 & 17 \\
\hline $\begin{array}{l}\text { Heat Load } \\
\text { Index (HLI) }\end{array}$ & $\begin{array}{l}\text { Unitless index that accounts for slope, aspect, } \\
\text { latitude, and potential direct incident radiation. } \\
\text { Smaller values correspond to less heat loading } \\
\text { and larger values correspond to more heat loading. }\end{array}$ & $\begin{array}{l}\text { Computed from DEM using the } \\
\text { Geomorphometry and Gradient Metric } \\
\text { ArcGIS Toolbox v2.0 (Evans et al. 2014) }\end{array}$ & 0.22 to 1.03 & 0.69 \\
\hline $\begin{array}{l}\text { Topographic } \\
\text { Position Index } \\
\text { (TPI) }\end{array}$ & $\begin{array}{l}\text { Unitless index that expresses relative ridge or } \\
\text { valley position by comparing the elevation of } \\
\text { each cell in a DEM to the mean elevation of a } \\
\text { specified neighborhood (here, } 1000 \mathrm{~m} \text { ) around } \\
\text { that cell. More negative values correspond to } \\
\text { valleys and more positive values correspond } \\
\text { to ridges. }\end{array}$ & $\begin{array}{l}\text { Computed from DEM using the Land } \\
\text { Facet Corridor Designer ArcGIS Toolbox } \\
\text { (Jenness et al. 2013) }\end{array}$ & -231.84 to 277.11 & 2.81 \\
\hline $\begin{array}{l}\text { Topographic } \\
\text { Wetness Index } \\
\text { (TWI) }\end{array}$ & $\begin{array}{l}\text { Steady-state wetness index that expresses } \\
\text { flow-accumulation as a function of both slope and } \\
\text { upstream contributing area, thus reflecting } \\
\text { potential site moisture balance. Smaller TWI values } \\
\text { correspond to less potential moisture, larger TWI } \\
\text { values correspond to more potential moisture. }\end{array}$ & $\begin{array}{l}\text { Computed from DEM using the } \\
\text { Geomorphometry and Gradient Metric } \\
\text { ArcGIS Toolbox v2.0 (Evans et al. 2014) }\end{array}$ & 3.42 to 16.98 & 5.89 \\
\hline
\end{tabular}

${ }^{1}$ Areas above $1800 \mathrm{~m}$ were categorically excluded to ensure that sites would be within the elevational range where forest management activities in this region are most likely to occur. Furthermore, large swaths of the highest elevations burned at high severity, limiting accessible interfaces with unburned or low-severity burn patches, which was an important criterion in site selection.

located within the resultant combinations. These strata did not factor into data analysis but were used solely to ensure that sites were distributed across the range of topographic settings in the study area. TWI is a proxy for potential site moisture (Gessler et al. 1995), and HLI reflects insolation, based on slope, aspect, and latitude (McCune and Keon 2002).

I sought to isolate the effect of topoclimate by controlling for other factors that were likely to influence regeneration. First, I included only areas that burned at high severity, based on differenced Normalized Burn Ratio (dNBR) classes from the Monitoring Trends in Burn Severity program (MTBS; Eidenshink et al. 2007). ${ }^{3}$ Doing so ensured that all juveniles therein had established since fire and also minimized the effect of intact canopy on localized growing conditions. Second, study sites were located at least $25 \mathrm{~m}$ from unburned and lowseverity burn patches to further minimize live canopy influence, but no more than $75 \mathrm{~m}$ from such patches to increase the likelihood of adequate seed source. At several sites, on-the-ground conditions were inconsistent with the dNBR classes (Cansler and McKenzie 2012), so these sites were shifted to meet severity criteria. Finally, sites were excluded from areas that were treated prior to the Tripod Fire (e.g., with fuel treatments) or post fire (e.g.,

${ }^{3}$ Data are available at https://www.mtbs.gov/direct-download aerial mulching or salvage logging), based on available data (Prichard and Kennedy 2014). I used ArcMap version 10.4 (ESRI 2014) for spatial data processing and site geolocation.

\section{Field data collection}

In a $30 \mathrm{~m}$ diameter plot at each of 51 sites, I collected data on post-fire juvenile establishment and growth, post-fire stand structure, and ground cover. I recorded juvenile trees established since fire in five $5 \mathrm{~m}$ radius subplots (392.5 $\mathrm{m}^{2}$ total area) arrayed in cardinal directions from plot center, with one subplot at the center. Following a strict algorithm based on subplot-level densities (sensu Harvey et al. 2016, Kemp et al. 2016; Additional file 1), I selected a random subset of juveniles for measuring total height $(\mathrm{cm})$ and interannual growth (distance between terminal bud scars). I recorded any evidence of animal browsing, other damage, and structural features that may have affected germination or establishment (e.g., nurse objects that may facilitate these processes by ameliorating microclimatic conditions).

In each plot, I tallied snags by size class and noted the presence of extant cones on snags of lodgepole pine, which are serotinous in this region. I estimated the percentage cover of juvenile trees, live shrubs, other vegetation, dead wood, bare ground, and rock in each plot. From the center of the central plot, I used a laser 
rangefinder to measure the distance to the nearest live, mature tree of all conifer species.

\section{Climate and growing condition variables}

I analyzed climate-growth relationships using mean monthly temperature, total monthly precipitation, and 1-month standardized precipitation-evapotranspiration index (SPEI) for Washington's Climate Division 6 (East Slope Cascades), obtained from the Westwide Drought Tracker (Abatzoglou et al. 2017). ${ }^{4}$ I specifically used divisional data rather than local station data to capture climatic variations occurring at a spatial extent larger than the study area-and therefore the "average" experience of all study sites-to evaluate if and how the topographic setting of each site modulated broader climatic variations. Using divisional data eliminated the potential bias of applying local station data to sites at variable distances from stations, and dendrochronology studies have shown that growth is more strongly correlated with divisional data than with station data (Peterson and Peterson 2001; Gray et al. 2004).

SPEI is a drought index that expresses deviations from the average water balance at a given site (Vicente-Serrano et al. 2010). It is a biophysically meaningful indicator that incorporates the influence of temperature on evaporative demand and uses the difference between precipitation and potential evapotranspiration to capture moisture balance deficit or surplus (Stephenson 1998). SPEI can be computed to "accumulate" antecedent conditions for a specified number of prior months, but I elected to use 1month SPEI to examine climate-growth relationships at a monthly resolution.

\section{Statistical analyses}

To examine the relationship between topographic setting and patterns of establishment and growth, I used a fourstep modeling approach. First, I predicted species presence and absence as a function of multiple topographic metrics (Table 1) and other ecologically relevant predictors (e.g., distance to seed source). Second, I modeled juvenile density for all species and individual species as a function of those same independent variables. Third, I compared establishment year patterns within and across species and examined correlations between annual establishment rates and climatic conditions. Finally, I generated time series of annual growth of lodgepole pine to examine climate-growth relationships and any topoclimatic influence on these relationships.

I examined pair-wise plots of predictor variables for collinearity to confirm that dropping covariates was not warranted. Because seed source was not present for

${ }^{4}$ Westwide Drought Tracker data are calibrated to a reference period of 1895 to 2010 and are available at https://wrcc.dri.edu/wwdt/time/ every species at every site, I generated an ordinal variable to account for these unknown distances by binning known distances for each species into $25 \mathrm{~m}$ intervals and setting unknown distances equal to the largest bin values plus one. In this way, the species-specific models included distances to conspecific seed source, not simply distance to any seed source. I centered and scaled all predictor variables prior to analyses to allow for direct comparison of effect sizes across variables. Unless otherwise noted, the unit of analyses was the site $(n=51)$. Because sampling occurred during the 2016 growing season, I excluded any 2016 germinants and growth from analyses. I performed these analyses in $\mathrm{R}$ version 3.4.3 (R Core Team 2017).

\section{Species presence and absence}

I modeled the presence of Douglas-fir, Engelmann spruce, ponderosa pine, and western larch using four logistic regression models (Dobson and Barnett 2008)..$^{5}$ All predictor variables were initially included in each model, and I trimmed these saturated models by iteratively removing the least significant terms and evaluating potential model improvement with the Akaike information criterion (AIC). Compared across competing models, AIC reflects model fit with a penalty for increased model complexity (Akaike 1973; Aho et al. 2014). I assessed model calibration with the Hosmer-Lemeshow goodness-of-fit test using a group size of 10, as recommended for the size of this dataset (Hosmer and Lemeshow 1980; Paul et al. 2013). Finally, to assess how well the models discriminated between outcomes, I examined the area under the curve (AUC) of a receiver operating characteristic (ROC) curve, which illustrates the tradeoff between model sensitivity (ability to correctly classify presences) and model specificity (tendency to incorrectly classify presences; Fawcett 2006). I examined model residuals for spatial autocorrelation using Moran's I and semivariograms (Fortin and Dale 2005; Dormann et al. 2007). I used the standard statistical package in $R$ for the logistic regression models, the package Resourceselection (Subhash et al. 2019) for the HosmerLemeshow test, the package pROC (Xavier et al. 2011) for generating ROCs, and the packages gstat (Pebesma and Gräler 2018) and ape (Paradis 2018) for assessing spatial autocorrelation.

\section{Species density}

I modeled the counts of each species and all species using generalized linear models, examining whether

\footnotetext{
${ }^{5}$ Occurrence (presence or absence) models were not constructed for all species combined because juveniles were present on every site sampled. Occurrence models for subalpine fir and lodgepole pine did not converge, because juveniles of these species occurred on only four sites and at all but seven sites, respectively.
} 
overdispersion in the count data (having a variance greater than the mean) or zero-inflation (having excess zeros) affected model fit (Martin et al. 2005; Dobson and Barnett 2008). To correct for variability in sampling area, I included an offset variable (log[area $]$ ) in each model (Zuur et al. 2009; Kotze et al. 2012). In all cases, a negative binomial distribution, which includes a dispersion parameter, was an improvement over a Poisson distribution, per the likelihood ratio test (Zuur et al. 2009; Lewis et al. 2011) and several other model-selection criteria (Additional file 1). Neither zero-inflated Poisson nor zero-inflated negative binomial models were improvements over the negative binomial models, as evaluated by Vuong's likelihood ratio test for non-nested models (Vuong 1989; Lewis et al. 2011), AIC, and a comparison between predicted and observed values (Additional file 1). In each model, I initially retained all covariates then iteratively trimmed these saturated models based on AIC and the likelihood ratio test. The count model for lodgepole pine included the covariate of extant cones on lodgepole pine snags.

I evaluated model fit with Spearman's rank correlation (Spearman 1904) between observed and predicted values, with the Pearson chi-squared goodness-of-fit test (Zuur et al. 2009), and by computing the proportional increase in deviance explained over the null (pseudo $R^{2}$; Dobson and Barnett 2008). I assessed models for heteroscedasticity (non-constant variance in the error terms) by plotting residuals and observed values against fitted values (Additional file 2). I also plotted residuals against leverage to determine if any sites were exerting inordinate influence. No sites exceeded a Cook's distance of 1 (Cook 1977), which would suggest that further examination of influence is warranted (Zuur et al. 2009), but I iteratively dropped sites with the highest leverage to evaluate model sensitivity. These exclusions resulted in little change to parameter estimates, and all sites were retained in the final models. Finally, I examined model residuals for spatial autocorrelation using Moran's I and semivariograms (Fortin and Dale 2005; Dormann et al. 2007).

I used the R packages MASS (Ripley et al. 2019) and pscl (Jackman 2017) for negative binomial models (including the zero-inflated models, which were evaluated but not used), the package lmtest (Zeileis and Hothorn 2002) for likelihood ratio tests, the package nonnest2 (Merkle et al. 2018) for Vuong's test for non-nested models, and the packages gstat (Pebesma and Gräler 2018) and ape (Paradis 2018) for assessing spatial autocorrelation.

\section{Years of establishment}

By counting bud scars and measuring distances between them, I determined establishment year and annual height growth for a random subsample of juveniles at each site (Additional file 1). Bud-scar counts can underestimate age for some species and especially for older individuals (Urza and Sibold 2013; Hankin et al. 2018), but I did not apply a blanket correction factor because underestimation biases vary with age and height, and sampled juveniles were highly variable in both. All juveniles established after the fire in 2006, which decreased the likelihood of inaccurate aging.

I used the non-parametric Kruskal-Wallis rank sum test (Kruskal and Wallis 1952) and subsequent Dunn's test (Dunn 1961) to make pairwise comparisons of earliest establishment year between species (McGarigal et al. 2000). I used multiple linear regression to examine if establishment year or topographic metrics were strong predictors of maximum annual growth rates. To investigate the relationship between establishment rates and growing conditions, I calculated Pearson correlations (Pearson and Erdmann 1896) between annual establishment rates and mean monthly temperature, total monthly precipitation, and SPEI.

\section{Climate-growth relationships}

I examined climate-growth relationships for lodgepole pine, focusing on this species because of its prevalence and early establishment after fire, which afforded a longer growth time series than other species. Furthermore, bud-scar identification is reliable for lodgepole pine, especially for the most recent years of growth (Urza and Sibold 2013). I used individuals that had established within the first two years since fire to ensure that every tree was close in age. To ensure adequate sampling depth for all years, I considered only the 14 sites that had at least 10 such trees.

To develop site-level growth chronologies, I adapted standard dendrochronological techniques to the heightgrowth time series of each tree, using the dplR package in R (Bunn 2010; Bunn et al. 2018). Each series was detrended with a linear regression model. A standardized growth index series was then created for each tree by dividing the raw growth measurement for each year by the regression value for that year. This removed any agerelated growth trend, which I verified with a visual examination of the growth index series. I created site-level chronologies by aggregating the standardized series together by year using a biweight robust mean (Bunn 2010).

I investigated climate-growth relationships by calculating Pearson product-moment correlations between site-level chronologies with climate variables for years since fire. I used mean monthly temperature, total monthly precipitation, and SPEI from the year prior to the season of growth through the year concurrent with growth. In other words, growth in a given year was related to the growing conditions of that year and of the prior year to capture any lagging climatic influences on 
growth. To test if the strength of the climate-growth relationships varied across topographic settings-for example, if conditions in some settings were decoupled from broader climatic variability-I regressed these correlation coefficients against the topographic metrics. I also regressed the correlation coefficients against sitelevel juvenile density to examine if neighborhood conditions strengthened or diminished any growth response to climatic variability.

\section{Results}

\section{Species presence and density}

Conifer juveniles were present at every site sampled, with variability in density and species representation (Table 2, Fig. 2). Of the topographic metrics examined, elevation most consistently accounted for the presence and abundance of species (Table 3). Western larch, lodgepole pine, Engelmann spruce, and subalpine fir ${ }^{6}$ occurred more frequently and at greater densities at the highest-elevation sites, whereas ponderosa pine and Douglas-fir were more prevalent at the lowestelevation sites. Both lodgepole pine and ponderosa pine occurred at higher densities at sites with higher heat load (per HLI). Engelmann spruce was more likely to occur in ravines and valleys (per TPI), whereas ponderosa pine was less likely to occur and less prevalent on slopes and in valleys. Few topographic patterns emerged for western larch or Douglas-fir presence and density, although Douglasfir density was highest on sloped sites.

Distance to live seed source limited regeneration (Fig. 3). Juveniles of each species, except lodgepole pine, were rarely observed when live, conspecific seed source was more than $75 \mathrm{~m}$ away (only seven instances). Lodgepole pine was the only species for which greater distance to live seed source was not associated with lower densities. A serotinous species, lodgepole pine was more likely to occur at sites where snags had cones (Fig. 3).

\section{Annual establishment}

For the most common species, recruitment consistently occurred every year since fire across sites (Fig. 4). Based on bud-scar reconstruction of establishment years, some lodgepole pine and ponderosa pine germinated in the late summer or early fall of 2006 immediately following the fire, which passed through the majority of the study sites between late July and late August. No subalpine fir or western larch recruited before 2009 (Fig. 5), although these species were observed at only four and ten sites,

\footnotetext{
${ }^{6}$ Because subalpine fir was present at only four sites, I did not generate occurrence or count models for the species. However, all four of these sites were above $1315 \mathrm{~m}$.
}

respectively. Sites with the oldest individuals (earliest establishment years) also had maximum annual growth rates for lodgepole pine, ponderosa pine, and Douglas-fir $(t=$ $-8.459, \mathrm{df}=37, P<0.001 ; t=-4.204, \mathrm{df}=18, P<0.001$; and $t=-2.567, \mathrm{df}=22, P<0.05$, respectively). Most juveniles recruited between 2009 and 2012. After 2011, recruitment rates declined for lodgepole pine, ponderosa pine, and Douglas-fir. Annual establishment rates for both lodgepole pine and ponderosa pine were positively correlated $(r>0.6, P<0.05)$ with April and May SPEI values. Rates for all species except western larch were positively correlated $(r>0.6, P<0.05)$ with SPEI values of at least one month during the subsequent spring (April, May, or June); correlations were particularly strong for lodgepole pine $(\mathrm{r}>0.8, P<0.01)$. In summary, higher establishment rates were associated with cooler, moister conditions (as indicated by positive SPEI values).

\section{Climate-growth relationships}

Lodgepole pine growth for a given year was most strongly and consistently correlated with climatic conditions of the previous summer and fall (Fig. 6, Additional file 3). The directions of these relationships were consistent across sites, but the strengths of the relationships were variable and did not follow a consistent pattern across topographic settings. At all sites, growth was negatively correlated with SPEI values of the prior July (five sites had correlation coefficients $\mathrm{r}<-0.6, P<0.1$ ). In other words, warm, dry Julys tended to precede more growth in the subsequent year, and cool, moist Julys preceded less growth. Conversely, growth was positively correlated with SPEI values of the prior August and September (seven sites in August and five sites in September had correlation coefficients $\mathrm{r}>0.6, P<0.1$ ). Growth tended to be negatively correlated with SPEI values of the prior October and November across all sites (although only one site each month had a correlation coefficient $\mathrm{r}<-0.6, P<0.1)$. On the other hand, for the year concurrent to growth, a consistent directionality in climate-growth correlations did not emerge for any month. Rather, the few strong correlations were scattered across different sites and months (Fig. 6).

Climate-growth correlations did not map onto the study area in any strong topographic patterns per linear regression, but they did vary subtly with juvenile density. The densest sites had the weakest (least negative) relationship with SPEI values for the prior July $(t=2.088, \mathrm{df}=12$, $P<0.1$ ), meaning that they had less growth than sparser sites when the prior July was droughty (which otherwise corresponded with enhanced growth). Denser sites also had the weakest (least positive) relationship with SPEI for the prior August $(t=-2.257, \mathrm{df}=12, P<0.05)$, meaning that they had less growth when the prior August was cooler and moister (which otherwise corresponded with 
Table 2 Range and mean of juvenile density and annual growth (measured to the nearest $\mathrm{cm}$ ) and percentage of sites at which each species was present. Sites were sampled in 2016 on the Tripod Complex fires in the Okanogan-Wenatchee National Forest, Washington, USA

\begin{tabular}{|c|c|c|c|c|c|}
\hline Species & Density range (stems ha ${ }^{-1}$ ) & Density mean (SE) $\left(\right.$ stems ha ${ }^{-1}$ ) & Growth range $\left(\mathrm{cm} \mathrm{yr}^{-1}\right)$ & Growth mean (SE) $\left(\mathrm{cm} \mathrm{yr}^{-1}\right)$ & Frequency (\%) \\
\hline Subalpine fir & 0 to 127 & $4(<1)$ & 3 to 13 & $7(<1)$ & $\overline{8}$ \\
\hline Western larch & 0 to 5118 & $164(15)$ & 1 to 67 & $10(<1)$ & 20 \\
\hline Lodgepole pine & 0 to 28928 & $3781(114)$ & 1 to 75 & $16(<1)$ & 86 \\
\hline Engelmann spruce & 0 to 806 & $35(3)$ & 1 to 19 & $5(<1)$ & 20 \\
\hline Ponderosa pine & 0 to 3158 & $387(16)$ & 2 to 45 & $14(<1)$ & 51 \\
\hline Douglas-fir & 0 to 1401 & $139(5)$ & 2 to 30 & $7(<1)$ & 65 \\
\hline All species & 102 to 29234 & $4511(115)$ & 1 to 75 & $15(<1)$ & 100 \\
\hline
\end{tabular}

enhanced growth). Thus, regardless of correlation direction, the climate signal in height growth was weaker at denser sites.

\section{Discussion}

\section{Spatial patterns of juvenile establishment}

A decade after fire, conifer juveniles had established at every site, with considerable variability in time, in space, and across species. As anticipated, distance to seed source was a major control on where and when juveniles established, but topographic setting also determined species presence and juvenile density. These spatial patterns are consistent with the autecology of each species: the infrequent occurrence of subalpine fir and Engelmann spruce is not surprising, given that no study sites were above $1800 \mathrm{~m}$. With relatively high rates of transpiration, these co-occurring species are more successful in cooler, moister settings like cold-air drainages (Burns and Honkala 1990). Similarly, western larch was most prevalent at higher sites. The shade intolerance of this species likely precluded establishment at sites where extensive shrub cover had taken hold.

Shade intolerant ponderosa pine was more prevalent at lower elevations on warmer, drier topographic convexities, while lodgepole pine densities were greatest on warm sites at higher elevations, even within topographic concavities.

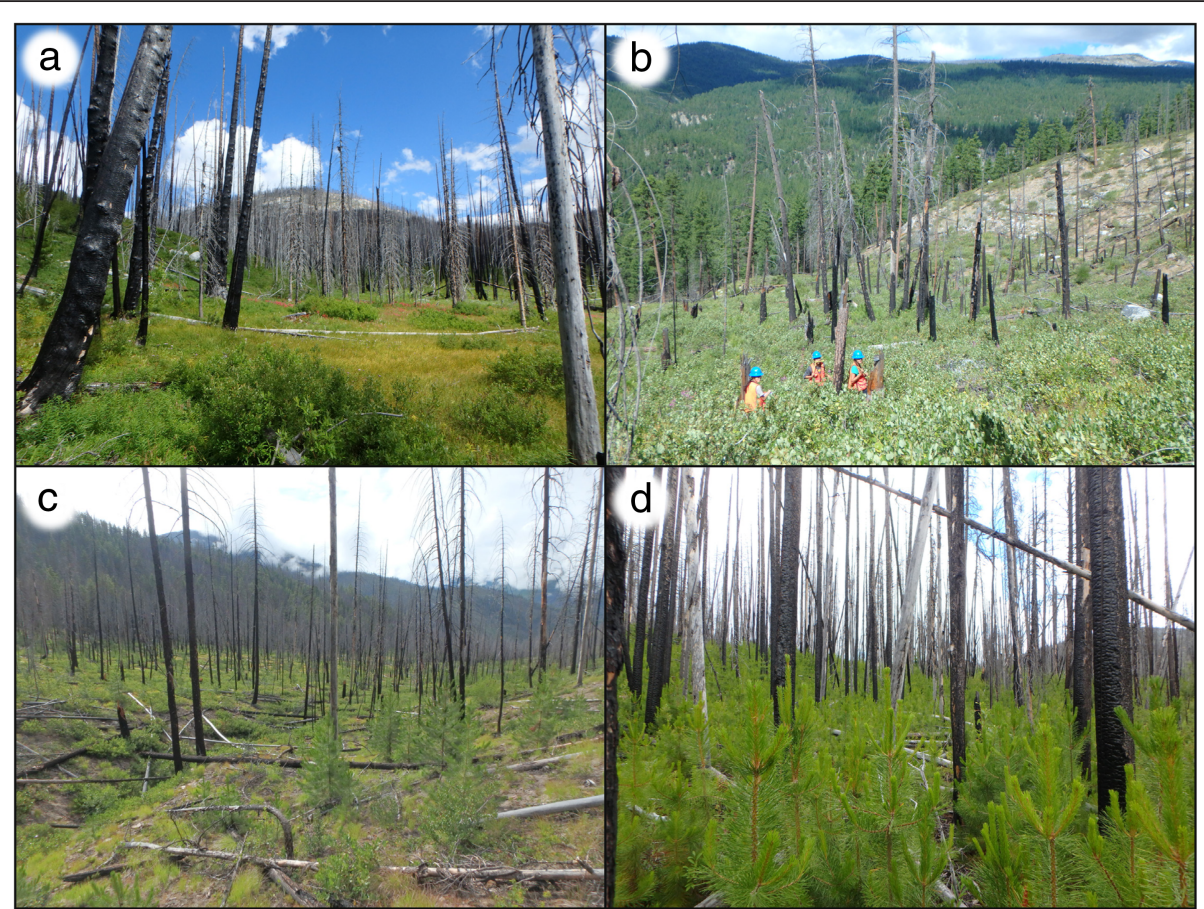

Fig. 2 Variability in conifer regeneration across the across the Tripod Complex study area, within the Okanogan-Wenatchee National Forest, Washington, USA. Images are from sampling in 2016. Some sites had very sparse regeneration (a), some were dominated by Ceanothus spp. (b), others had moderately dense regeneration $(\mathbf{c})$, and several had very dense lodgepole pine regeneration (d) 
Table 3 Results of the logistic regression (presence or absence $=p / a$ ) and negative binomial (count) models of post-fire juvenile establishment. Coefficients and their levels of significance (if $P<0.05$ ) are reported for all covariates retained in the final models. Covariates were centered and scaled prior to model construction to facilitate comparison. Performance statistics are given in Table 4 Asterisks indicate levels of significance for parameter coefficients: ${ }^{* *}=P<0.001,{ }^{* *}=P<0.01,{ }^{*}=P<0.05$. Models were for field data collected in 2016 on the Tripod Complex fires in the Okanogan-Wenatchee National Forest, Washington, USA

\begin{tabular}{|c|c|c|c|c|c|c|c|c|c|c|c|c|}
\hline \multirow[b]{2}{*}{ Covariates } & \multicolumn{2}{|c|}{ All species } & \multicolumn{2}{|c|}{ Western larch } & \multicolumn{2}{|c|}{ Lodgepole pine } & \multicolumn{2}{|c|}{ Engelmann spruce } & \multicolumn{2}{|c|}{ Ponderosa pine } & \multicolumn{2}{|c|}{ Douglas-fir } \\
\hline & $\overline{\mathrm{p} / \mathrm{a}^{1}}$ & count & $\mathrm{p} / \mathrm{a}$ & count & $\overline{p / a^{1}}$ & count & $\mathrm{p} / \mathrm{a}$ & count & $\overline{\mathrm{p} / \mathrm{a}}$ & count & $\bar{p} / \mathrm{a}$ & count \\
\hline Elevation (m) & -- & & $0.010^{*}$ & $2.159^{* *}$ & -- & $0.555^{*}$ & $0.006^{* *}$ & $1.442^{* *}$ & $-0.005^{*}$ & $-2.603^{* * *}$ & & $-0.457^{*}$ \\
\hline Slope (degrees) & -- & -0.234 & & & -- & & 0.118 & 0.907 & $-0.176^{*}$ & & & $0.433^{*}$ \\
\hline Heat load index & -- & & & & -- & $-0.479^{*}$ & & & & $-0.680^{*}$ & & \\
\hline Topographic position index & -- & & & & -- & $-0.610^{*}$ & $-0.026^{*}$ & $-1.655^{*}$ & $0.020^{*}$ & $1.157^{* *}$ & & -0.292 \\
\hline Topographic wetness index & -- & & & & -- & & & & & & & \\
\hline Shrub cover (percentage) & -- & $-0.421^{* * *}$ & 0.052 & & -- & $-0.427^{*}$ & & & & & $0.046^{*}$ & \\
\hline $\begin{array}{l}\text { Distance to live seed } \\
\text { source }(m), \text { binned }^{2}\end{array}$ & -- & $-0.399^{* *}$ & $-0.999^{* *}$ & $-2.152^{* * *}$ & -- & $0.3282^{*}$ & -0.417 & -0.596 & -0.212 & & $-0.566^{* *}$ & $-1.070^{* * *}$ \\
\hline Extant cones on snags & -- & -- & -- & -- & -- & $1.132^{*}$ & -- & -- & -- & -- & -- & -- \\
\hline
\end{tabular}

${ }^{1}$ Occurrence (presence or absence) models were not constructed for all species combined because juveniles were present on every site sampled. Neither an occurrence model nor a count model for subalpine fir was constructed because subalpine fir juveniles occurred on only four sites, so the models did not converge. Similarly, the occurrence model for lodgepole pine did not converge, as it occurred on all but seven sites. Models that were not run or variables that were not included are indicated by dashes (--)

${ }^{2}$ For the all species count model, I used minimum distance to live seed source of any species; for the species-specific models, I used bins of minimum distance to live conspecific seed source. Distance to seed source was not captured for every species at every site (e.g., due to true absence or no clear sightline) and so I generated an ordinal variable to account for these unknown distances: I binned known distances by $25 \mathrm{~m}$ intervals and set unknown distances equal to the largest bin value plus one

The fact that Douglas-fir density was highest in sloped yet valley-like positions suggests the species' need for both adequate moisture and drainage. The positive association between Douglas-fir presence and shrub cover may reflect a potential facilitative effect of nitrogen-fixing species in the genus Ceanothus L. and Alnus rubra Bong. on Douglas-fir establishment (Burns and Honkala 1990).

The lack of prominent spatial patterns for Douglas-fir presence suggests that topoclimatic conditions did not strongly exceed the range of biophysical tolerances for the species. Alternatively, factors that limit the occurrence and abundance of these species may be heterogeneous at scales finer than predictor variable resolution (McKenzie et al. 2003). For example, the proxy for site moisture balance (TWI) did not emerge as a predictor for any species, even though moisture balance can be a limiting factor for other species examined. TWI simply may not reflect fineror broader-scale hydrologic dynamics that act on juvenile establishment (Wiens 1989). Such spatially structured dynamics that are not captured likely contributed to the small degree of positive spatial autocorrelation in the residuals of two models (Table 4).

\section{Seed source constraints}

Seed availability is a fundamental determinant of successional patterns, especially after intense disturbance (Turner et al. 1999; Johnstone et al. 2016). Post-fire establishment can sharply decline with increasing distance to live seed source (Donato et al. 2009; Dodson and Root 2013; Kemp et al. 2016). That pattern held here, even with an effort to ensure adequate seed source by locating sites within $75 \mathrm{~m}$ of unburned or low-severity burn patches: distance to seed source was a significant constraint on the establishment of all species except lodgepole pine (Table 3). This suggests that establishment rates for non-serotinous species were very likely lower in the interiors of large, high-severity burn patches where seed availability was reduced and extensive shrub cover may have taken hold-particularly sprouting shrubs and those with heat-stimulated soil seedbanks (e.g., Ceanothus spp.; Donato et al. 2009, Romme et al. 2016, Young et al. 2019). Such areas on the Tripod Fire are not trivial: approximately $52 \%$ of the total Tripod Fire area and $65 \%$ of high-severity burn areas were not within $75 \mathrm{~m}$ of an unburned or low-severity burn edge and were not examined in this study. These high proportions are consistent with observations that-relative to other forest types in the region-dry montane and subalpine forests of the North Cascades have higher proportions of high-severity burn patches during dry years and within larger fires, as well as significant increases in the size and interior area of high-severity burn patches as fires get larger (Cansler and McKenzie 2014). These patterns, and the likely decrease in persistent unburned patch density (especially of smaller sizes) under more extreme fire weather conditions (Kolden et al. 2015; Krawchuk et al. 2016), suggest that seed availability will continue to be a major limiting factor to post-fire recovery in these forests.

However, many sites had minimal establishment even in the presence of live, mature conspecifics, suggesting that 


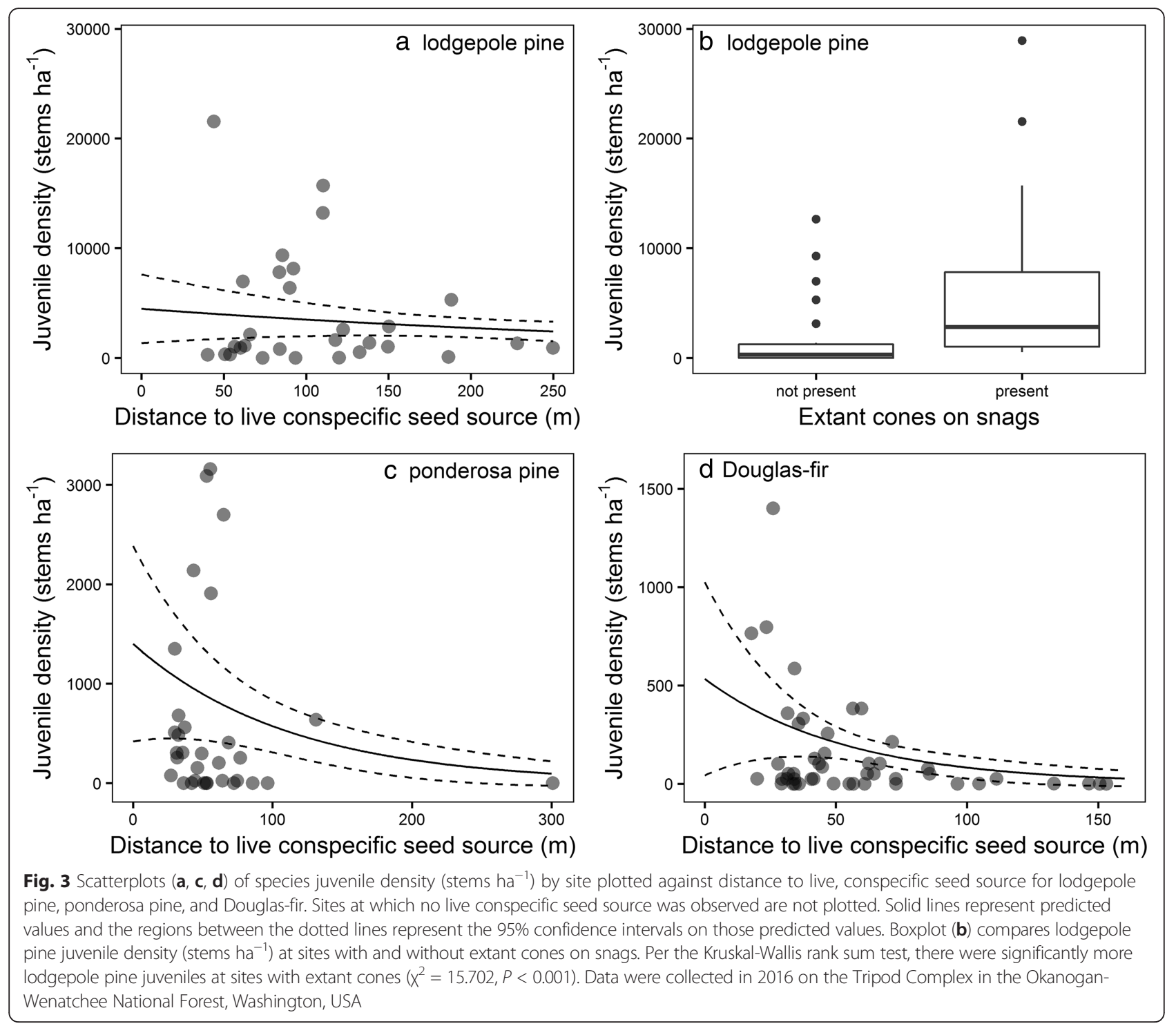

other unmeasured constraints were operating on establishment. Episodic seed production may have contributed to sparse or sporadic recruitment. Age and basal area of mature conspecifics can also dictate seed production, viability, and delivery (Burns and Honkala 1990; Krannitz and Duralia 2004). The spatial orientation of seed source, whether upslope or downslope from a site, depends on burn patterns (and therefore topography; Prichard and Kennedy 2014) and may affect seed delivery as well, although thermal updrafts and dispersal by animals may moderate this effect (Donato et al. 2009). Aboveground and belowground biotic interactions (e.g., facilitation), seed predation, and edaphic characteristics may also account for variability in juvenile density (Teste et al. 2009; Redmond et al. 2015). Finally, mature individuals of a given species may have established under anomalous climatic conditions that enabled them to overcome site-specific limiting factors at the time (e.g., during the Little Ice Age or other cool, moist periods; Brown 2006, Gray et al. 2006). Juveniles may now no longer be able to recruit at the same sites even in the presence of adequate seed source (Tepley et al. 2017; Stevens-Rumann et al. 2018). However, conditions for the first several years after the Tripod Fire were generally favorable for regeneration (cooler and with slightly more precipitation than average), so other factors such as episodic seed production were likely more important in constraining juvenile establishment.

Serotiny likely contributed to the robust regeneration of lodgepole pine. Lodgepole pine was the one species for which distance to live, mature individuals did not constrain juvenile density, and sites with cones on lodgepole pine snags had significantly more juveniles than sites where cones were not observed (Fig. 3). Both of these patterns suggest that serotiny 


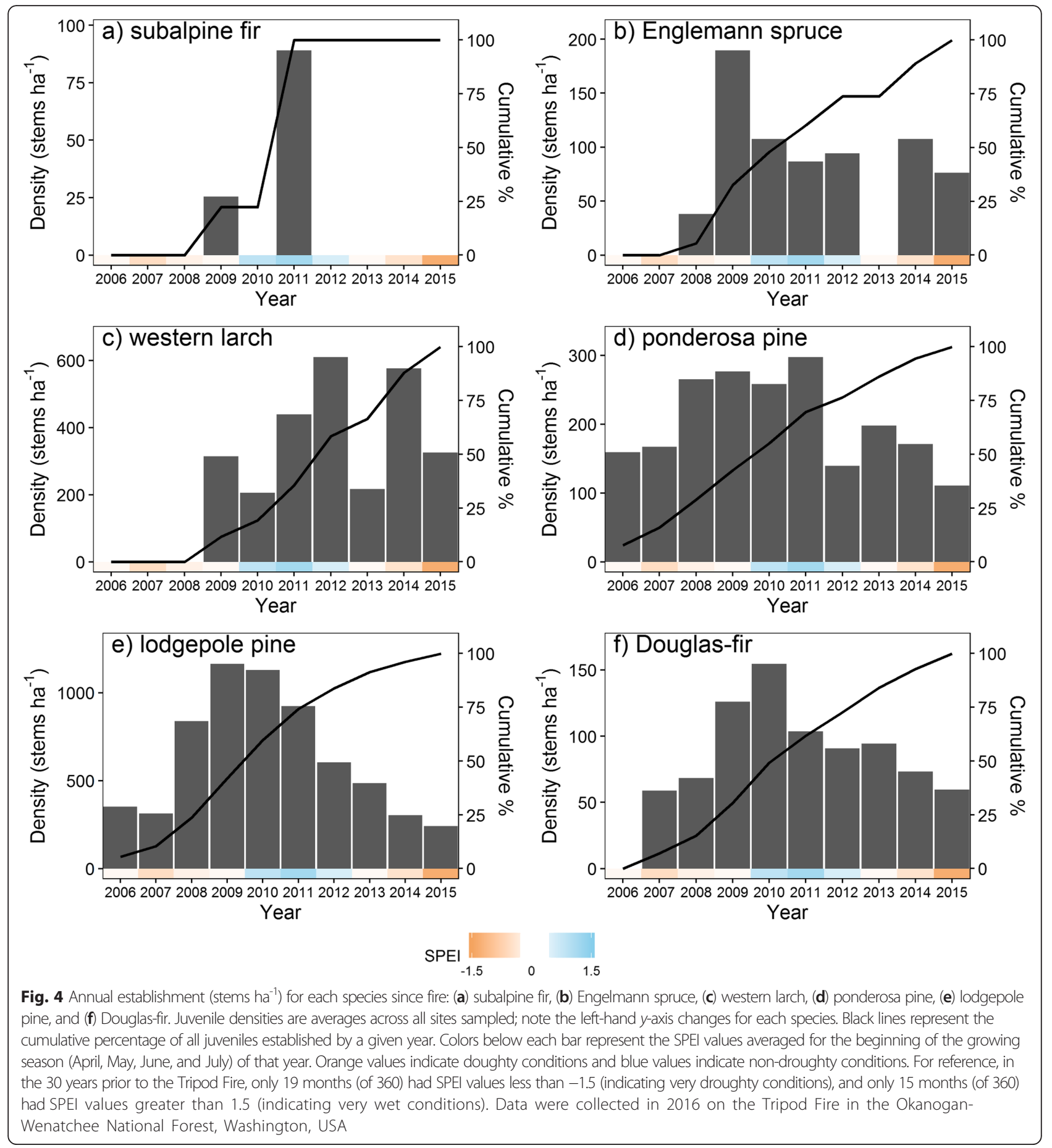

played a more important role in the recovery of this species than seed rain from live individuals. Furthermore, the long interval since prior fire and the high juvenile densities both within study sites and observed elsewhere in large burn patches further suggest that this trait was prevalent in these populations at the time of fire (Tinker et al. 1994). The fact that higher densities coincided with extant cones also suggests an indirect influence of fire effects (Turner et al. 1999; Donato et al. 2016): all sites had complete overstory mortality, but some sites may have experienced severe surface fires that killed the thin-barked lodgepole pine while opening cones and releasing seeds. Crown fires in other areas-particularly in the interiors of large, high-severity burn patches-may have completely consumed the aerial seed bank (Turner et al. 1999). 


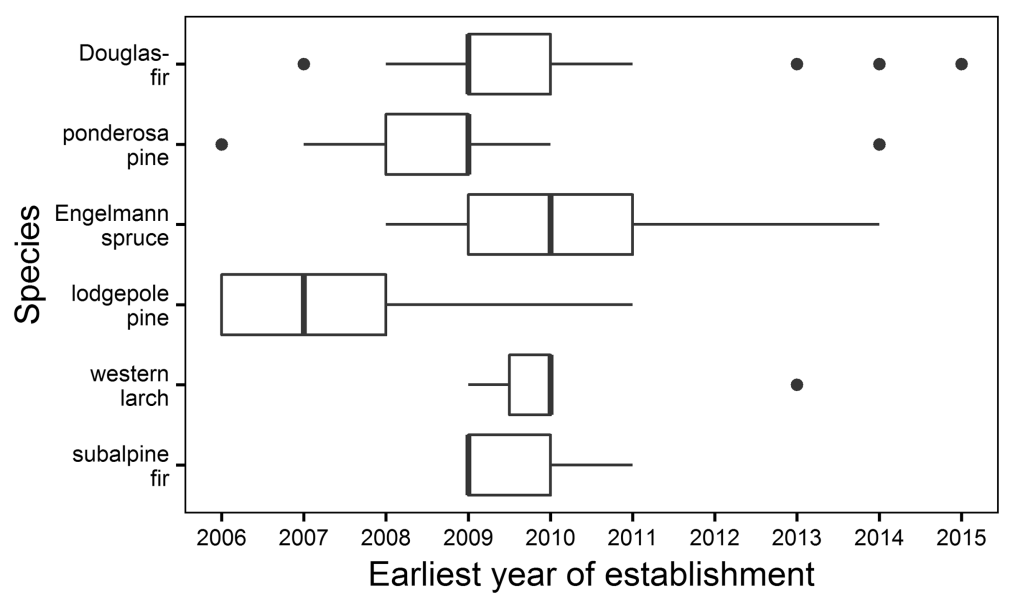

Fig. 5 The earliest year of establishment for each species across all sites. Per the Kruskal-Wallis rank sum test, there was a significant difference across species $\left(X^{2}=43.199, d f=5, P<0.001\right)$. A subsequent pair-wise comparison using Dunn's test confirms that the earliest year of establishment for lodgepole pine is significantly different than that of all other species; ponderosa pine's earliest year of establishment is significantly different than that of Engelmann spruce. Boxplot center line corresponds to the median, box edges correspond to the 25th and 75th percentiles, whiskers extend to values that are at most 1.5 times the inter-quartile range, and data points beyond the whiskers are plotted individually. Data were collected in 2016 on the Tripod Fire in the Okanogan-Wenatchee National Forest, Washington, USA

\section{Temporal patterns of juvenile establishment}

Temporal patterns in climatic variability contributed to the relatively robust and consistent establishment in the years since fire. Favorable climatic conditions likely ensured this establishment success: annual rates of establishment were positively correlated with SPEI values of the current and subsequent years, and the three most common species emerged every year since fire. These cool, moist climatic conditions of 2010 to 2012, which were associated with a cool phase of the Pacific Decadal Oscillation (PDO), were followed by warmer, drier conditions associated with a warm phase of the PDO and the 2013 emergence of a warm anomaly off the Pacific Coast (Cook et al. 2018). The arrival of these warmer, drier conditions may have contributed to declining establishment rates, but this trend also reflects increasingly constrained growing space, particularly at lodgepole pine-dominated sites.

In contrast to the favorable post-fire conditions, postfire drought has impeded establishment elsewhere (Harvey et al. 2016; Tepley et al. 2017; Stevens-Rumann et al. 2018). At broader temporal scales, establishment has been linked to multi-year and decadal modes of climatic variability across forest systems, with more establishment generally corresponding to cooler, moister periods (Woodward et al. 1995; Peterson and Peterson 2001; Gray et al. 2006). These modes of variability may exacerbate or ameliorate stressful conditions anticipated under climate change at some spatial scales (Walther et al. 2002). Relatively cool and moist conditions following the Tripod Fire helped to "lock in" robust establishment. Had post-fire conditions instead been droughty, establishment may have been far more protracted.
Finally, the variability observed is consistent with the well-documented prevalence of localized, divergent successional pathways (Kashian et al. 2005; Harvey and Holzman 2014) and, more broadly, the landscape heterogeneity typical of mixed-severity fire regimes (Agee 1993; Hessburg et al. 2005). It is important to note, however, that inferences from this study regarding heterogeneity in recovery cannot be extended into the interiors of large, high-severity patches, of which there were many within the Tripod Fire perimeter and other large fires in the North Cascades region (Cansler and McKenzie 2014; Reilly et al. 2017). Furthermore, this dataset does not capture juveniles that germinated post fire but did not survive to the time of sampling. Tracking mortality would provide further insights into how constraints operating on recruitment-climatic or otherwise-may shift in time and space.

\section{Annual growth response to climatic conditions}

Annual height growth of lodgepole pine juveniles clearly responded to broader climatic patterns, but the strength of these climate-growth relationships did not definitively change across topographic settings. These results do not suggest that annual growth rates per se are consistent across all settings. Indeed, maximum annual growth rates (unstandardized, site level) increased with elevation, suggesting a release from temperature and moisture stresses at higher elevations. Rather, the direction and magnitude of the correlations between standardized growth and climate did not strongly vary with topography, providing little evidence that topoclimatic influence decoupled site conditions from the prevailing macroclimate to a degree that was evident in growth. 


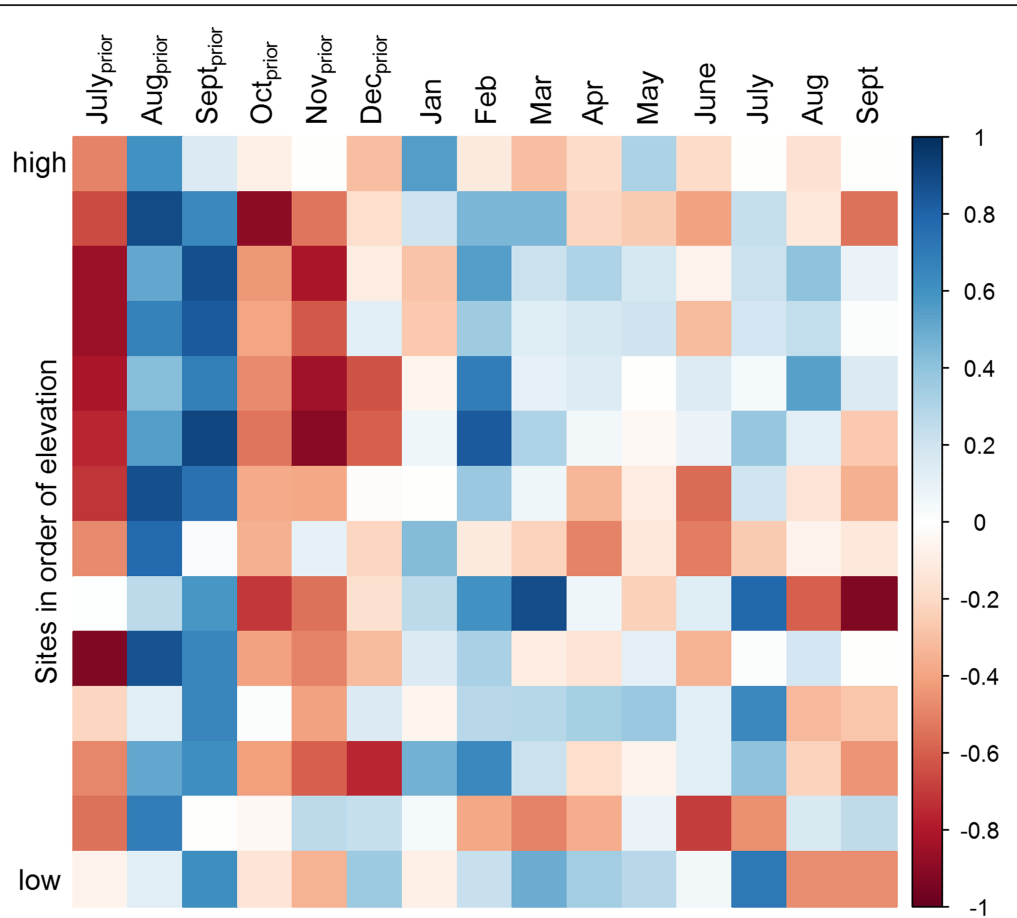

Fig. 6 Correlation coefficients (Pearson's) between lodgepole pine annual height growth at each site and standardized precipitation-evapotranspiration index (SPEI) values for months prior to the year of growth (July to Dec) and through the growing season. (Only these months are shown to facilitate readability and because very few correlations emerged before the prior July [seven months] and after the concurrent September [no months]. See Additional file 3 for a matrix of 24 months). To ensure adequate sampling depth, only 14 sites were considered in this analysis, and they are ordered with the lowest elevation site on the bottom of the matrix and the highest elevation site at the top. Color intensity indicates the magnitude of the correlation with dark blue indicating a strong positive correlation $(r=1)$ and dark red indicating a strong negative correlation $(r=-1)$. More negative SPEl values are indicative of droughty conditions while more positive SPEI values are indicative of non-droughty conditions. Thus, a positive correlation between growth and SPEl (blue squares) corresponds to more growth during less droughty conditions, while a negative correlation between growth and SPEI (red squares) corresponds to more growth during more droughty conditions. Despite a seemingly discernible pattern with elevation, correlation coefficients for any given month were not significantly related to elevation per linear regression. See Additional file 3 for correlation matrices of precipitation and temperature. Correlations are based on data collected in 2016 on the Tripod Fire in the Okanogan-Wenatchee National Forest, Washington, USA

Annual growth was particularly responsive to prioryear conditions, similar to lagging climatic signatures on radial growth in various forest systems (Brubaker 1980; Restaino et al. 2016; Andrus et al. 2018). The consistently weak response of growth to current-year conditions may be attributable to the fact that lodgepole pine shoots exhibit fixed growth, by which preformed stem units in the terminal buds elongate after winter dormancy (Kozlowski and Pallardy 1997). Therefore, prior-year conditions under which buds form may be

Table 4 Model performance for the logistic regression (occurrence) model and the negative binomial (count) model. Pseudo $R^{2}$ values indicate proportional increase in deviance explained over the null. Fit statistics indicate a significant lack of fit if $P$-values $<0.05$. Similarly, Moran's I indicates potential residual autocorrelation when $P<0.05$. Diagnostic plots for the count models are given in Additional file 2 . Models were for field data collected in 2016 on the Tripod Complex fires in the Okanogan-Wenatchee National Forest, Washington, USA. Models that were not run are indicated by dashes (--)

\begin{tabular}{|c|c|c|c|c|c|c|c|c|}
\hline & \multicolumn{4}{|c|}{ Logistic regression } & \multicolumn{4}{|c|}{ Negative binomial } \\
\hline & Pseudo $R^{2}$ & Hosmer-Lemeshow statistic & $A \cup C$ & Moran's I & Pseudo $\mathrm{R}^{2}$ & Pearson's statistic & Spearman's rank & Moran's I \\
\hline All species & -- & -- & -- & -- & 0.24 & $x^{2}=59.05, P=0.11$ & $\rho=0.49$ & $I=-0.01, P=0.91$ \\
\hline Western larch & 0.54 & $x^{2}=5.50, P=0.70$ & 0.94 & $I=0.02, P=0.49$ & 0.79 & $X^{2}=28.12, P=0.99$ & $\rho=0.57$ & $I=-0.05, P=0.43$ \\
\hline Lodgepole pine & -- & -- & -- & -- & 0.30 & $X^{2}=42.44, P=0.69$ & $\rho=0.57$ & $I=0.03, P=0.42$ \\
\hline Engelmann spruce & 0.34 & $x^{2}=5.55, P=0.70$ & 0.87 & $I=0.13, P=0.01$ & 0.50 & $X^{2}=58.74, P=0.12$ & $\rho=0.50$ & $I=0.07, P=0.10$ \\
\hline Ponderosa pine & 0.40 & $x^{2}=9.17, P=0.33$ & 0.89 & $I=0.09, P=0.05$ & 0.58 & $x^{2}=35.60, P=0.89$ & $\rho=0.73$ & $I=0.08, P=0.10$ \\
\hline Douglas-fir & 0.27 & $x^{2}=8.97, P=0.35$ & 0.86 & $I=0.10, P=0.05$ & 0.46 & $x^{2}=51.26, P=0.35$ & $\rho=0.53$ & $I=0.11, P=0.03$ \\
\hline
\end{tabular}


more important in determining height growth than current-year conditions.

Growth at most sites was positively correlated with winter precipitation (Additional file 3), highlighting the role of snowpack in minimizing the risk of winter injury (Germino et al. 2002) and in ensuring adequate moisture for preformed stem units to achieve their height growth potential (Hu et al. 2010). Snowpack contributions to soil moisture may also explain the directional switch in growth correlations with prior summer conditions. In July, soil moisture may have still been sufficiently high such warmer, drier mid-summer conditions (i.e., more negative SPEI values) did not hinder net carbon assimilation rates and therefore did not hinder investment in preformed stem units and carbohydrate reserves (Kozlowski and Pallardy 2002). By late summer, depleted soil moisture coupled with high vapor pressure deficits would have induced stomatal closure in isohydric species like lodgepole pine, and more summer rainfall would have been required to maintain higher rates of net carbon assimilation (Pataki et al. 2000; Hu et al. 2010). Relatively mild conditions in the late fall may have enabled continued carbon investments prior to winter dormancy (Fig. 6; Additional file 3).

Because radial growth occurs secondarily to stem elongation, an examination of radial growth may have revealed a stronger response to current-year climatic conditions than height growth, which is often complete early in the growing season (Kozlowski and Pallardy 1997; Misson et al. 2006). Under less favorable growing conditions, lodgepole pine has been shown to reduce radial growth to a greater degree than height growth (Claveau et al. 2002), and radial growth can be particularly sensitive to fine-scale variability in climate (Case and Peterson 2005). Accordingly, a topographic signal in the strength and direction of a climate-growth relationship, although not observed in height growth, may have been manifest in radial growth. Alternatively, the range of climatic conditions since fire, and any modulating influence of topographic setting on those conditions, may not have exceeded any thresholds that would differentially affect lodgepole pine height growth across topographic settings.

The relationship between annual height growth and climate varied subtly with stem densities. The climate signal in height growth was weaker at denser sites, suggesting that increased competition may shift resource allocation to root or lateral growth (Litton et al. 2003; D'Amato et al. 2013). Higher density may also dampen individual aboveground growth sensitivity to prevailing climatic conditions. Finally, juveniles themselves affect microclimate conditions such that higher densities may have moderated broader-scale climatic influences (von Arx et al. 2013; Dobrowski et al. 2015).

\section{Historical and future contingencies}

These post-fire recovery dynamics reflect the convergence of ecological, physiographic, and climatic influences operating at multiple spatial and temporal scales. The convergence suggests that the narrative of declining forest resilience under climate change may be warranted in some locations, but it is not-or is not yet-universal, when seed is readily available. Indeed, mean annual temperature in the Pacific Northwest increased by "only" 0.6 to $0.8^{\circ} \mathrm{C}$ over the twentieth century (1901 to 2012; Abatzoglou et al. 2014). Strong, widespread effects of climate change on fireprone forests and forest recovery will likely be more apparent under sustained warming and later in this century (Johnstone et al. 2016). The cool and moist post-fire conditions that facilitated robust regeneration observed here, along the eastern slopes of the North Cascades, will become increasingly rare. Washington temperatures are projected to increase 2.5 to $8{ }^{\circ} \mathrm{C}$ above twentieth century temperatures by 2100 (USGCRP 2018), and even though winter precipitation is projected to increase, decreasing snowpack will reduce long-term persistence of soil moisture (Harpold and Molotch 2015; Andrus et al. 2018). Even brief fluctuations in growing-season temperatures can rapidly deplete available moisture in some settings, and this will be increasingly common under continued warming (D'Odorico et al. 2000). As the intra-annual variability in climate-growth correlations suggests, regeneration dynamics may be highly sensitive to the timing of such fluctuations. Accordingly, even with available seed, some settings may soon cross limiting thresholds for juvenile conifer establishment and growth (Davis et al. 2019; Kemp et al. 2019), thereby amplifying the association between topographic setting and regeneration variability observed here. Furthermore, extreme fire weather and dry summer conditions in this region have been shown to override localized controls (e.g., topographic complexity, fuel continuity, and moisture) on burn patterns that may otherwise lead to more spatial heterogeneity (Cansler and McKenzie 2014). Continued warming and drier summers may amplify the size of high-severity burn patches in the future and reduce the interspersion of fire refugia, further limiting seed availability and the localized mediation of climatic conditions by surviving canopy (Cansler and McKenzie 2014; Dobrowski et al. 2015; Kolden et al. 2015).

Just as the historical contingency of post-fire climatic conditions affected regeneration, unforeseen contingencies in the future will also shape the system trajectory (Jackson et al. 2009). For example, these juveniles that established soon after the Tripod Complex fires may in fact be more vulnerable to future drought because their hydraulic architecture has not been preconditioned via early exposure to nonlethal drought stress to withstand future drought conditions (Kozlowski and Pallardy 2002; McDowell et al. 2008). A high-severity reburn in this recovering system may increase 
the likelihood of conversion to a persistent, non-forested state for decades (Prichard et al. 2017). On the other hand, areas that burned at lower severity and experienced a reduction in both surface fuel loads and small-diameter trees may now be more resilient to future fire; for example, by burning at lower severity or not at all in the future (Lyons-Tinsley and Peterson 2012; Larson et al. 2013; Prichard and Kennedy 2014).

In addition to these potential future contingencies, protracted recruitment patterns and divergent successional pathways hinder our ability to project system trajectories from initial post-fire regeneration (Kashian et al. 2005; Gill et al. 2017). The variability observed here, one decade after stand-replacing fire, underscores the importance of considering multiple facets of recruitment at longer time frames (e.g., both establishment rates and growth) as well as the individualistic dynamics of each species in projecting longer-term responses to climatic changes (Davis and Shaw 2001).

\section{Promoting recovery in an uncertain future}

The spatio-temporal dynamics documented in this study suggest where and when to prioritize management that promotes recovery or reduces vulnerability to future disturbance in the dry mixed conifer forests of the North Cascades. For example, the strong influence of distance to seed source on juvenile density highlights the importance of identifying and protecting live tree legacies and, more broadly, promoting the persistence and interspersion of unburned patches (Kolden et al. 2015; Kemp et al. 2016; Krawchuk et al. 2016). This also indicates that variability in burn patch size strongly influences spatial heterogeneity in recruitment, so promoting natural regeneration may be a viable management alternative to replanting in some areas with nearby seed source (Donato et al. 2009). However, continued warming and drier summers may override localized controls that otherwise promote spatial heterogeneity in high-severity burn patch size, shape, and abundance. A corresponding increase in the proportion of large, high-severity burn patches and a decline in the density of unburned patches, as predicted in these forest types (Cansler and McKenzie 2014; Kolden et al. 2015), may increasingly limit the viability of relying on natural regeneration.

These results also suggest that natural regeneration and establishment will be most successful under cool, moist conditions and in settings that are not severely moisture limited (Dodson and Root 2013; Harvey et al. 2016). Under droughty conditions and in warm, dry settings (e.g., low-elevation, south-facing slopes), replanting with drought-tolerant ecotypes or reducing moisture stress (e.g., via thinning) may be warranted (Hessburg et al. 2015). Conversely, cool, moist sites with robust recovery of drought-intolerant species may serve as localized climatic refugia that may be considered for protection (e.g., via grazing exclusions; Morelli et al. 2016). For species like lodgepole pine that can establish and grow across a range of topoclimatic conditions, density-dependent processes may be as or more important to consider than topographic setting in guiding management decisions. Nonetheless, the compounding effects of warming temperatures and more instances of extreme weatherwhich are likely to decrease seed availability via more and larger high-severity burn patches and via fewer unburned patches (Cansler and McKenzie 2014, Kolden et al. 2015), and which may impede juvenile establishment and survival-suggest that we may need to accept persistent transitions to non-forest in some burned areas while focusing recovery efforts on the highest priority areas.

Because snapshots in time are insufficient for projecting long-term recovery, a broad spatial and temporal scope that encompasses fine-scaled dynamics both within and across forested systems is needed to refine our understanding of how climate change may or may not impede post-fire regeneration. Increasingly, researchers are responding to this need by examining multiple fires across systems, although cross-region comparisons have required simplification of fine-scaled dynamics (Stevens-Rumann et al. 2018), and efforts to document multiple facets of recovery (e.g., both establishment rates and growth) remain rare (but see Tepley et al. 2017). At a minimum, longterm monitoring of both natural regeneration and the effectiveness of on-the-ground adaptation tactics will be important for continuing to refine our conceptual models and adaptation strategies to promote forest recovery in an uncertain future.

\section{Conclusions}

The narrative of recovery failure under climate change has not-or has not yet-played out since the 2006 Tripod Complex Fire on the eastern slopes of the North Cascades, a region in which relatively little work has been done to specifically track post-fire regeneration. Juvenile conifers established every year since fire, with approximately $85 \%$ of sites exceeding juvenile densities considered sufficient for regenerating a stand per regional stocking guidelines. ${ }^{7}$ Importantly, these sites were all within $75 \mathrm{~m}$ of unburned or low-severity burn

\footnotetext{
${ }^{7}$ Forest Service stocking guides for mixed conifer forests in the region suggest that a range of 745 to 1680 planted seedlings per hectare will regenerate a stand (depending on site productivity, planned thinnings, etc.; Seidel and Cochran 1981). On the other hand, state of

Washington Administration Code deems an area east of the Cascade crest "reforested" when 370 or more healthy seedlings per hectare have survived on site for at least one growing season (WAC 222-34-020). Of sites sampled, $82 \%$ met and $88 \%$ exceeded these prescribed densities. These stocking guidelines may be reasonable estimates for what is needed to ensure recovery, but because they are typically created with specific objectives in mind (e.g., maximizing yield), their application to natural regeneration can be limited.
} 
patches; it is very unlikely such densities occurred in the interior of the many large, high-severity burn patches on the Tripod Fire. Furthermore, the relatively cool and moist post-fire conditions that facilitated robust regeneration after the Tripod Fire will become increasingly rare, and seed availability will become increasingly limited if more area burns at high severity. And so, while these results suggest that declining forest resilience is not universal, the recovery that unfolded may be increasingly unlikely, especially in moisture-limited settings and in large, high-severity burn patches far from seed sources. Examining the spatio-temporal variability of multiple dimensions of regeneration, as this study does, and longterm monitoring will improve our predictions of where and when regeneration failure is most likely to occur, and how management may promote recovery under a changing climate.

\section{Additional files}

Additional file 1: Supplementary methods for analyses of data collected in 2016 on the Tripod Fire in the Okanogan-Wenatchee National Forest, Washington, USA. Table S1. A. Model diagnostics for candidate count models, including log-likelihood (logLik), Akaike information criterion (AIC), and dispersion, as indicated by $\varphi$. In all cases, a negative binomial model (NB) was retained over Poisson, zero-inflated Poisson (ZIP), and zero-inflated negative binomial (ZINB) candidate models. Dashes indicate metrics that were not applicable. Models were based on data collected in 2016 on the Tripod Fire in the Okanogan-Wenatchee National Forest, Washington, USA. (PDF $234 \mathrm{~kb}$ )

Additional file 2: Figure S2. A. Diagnostic plots for count models including fitted counts (fit cnt) versus observed counts (obs cnt), fitted counts versus deviance residuals (resid), and observed counts versus deviance residuals. Models were based on data collected in 2016 on the Tripod Fire in the Okanogan-Wenatchee National Forest, Washington, USA. (PDF $146 \mathrm{~kb}$ )

Additional file 3: Figure S3. A. Correlation coefficients (Pearson's) between lodgepole pine annual growth at each site and standardized precipitation-evapotranspiration index (SPEI) values for months prior to the year of growth (July to December) and through the growing season (January to September). To ensure adequate sampling depth, only 14 sites were considered in this analysis, and they are ordered with the lowest elevation site on the bottom of the matrix and the highest elevation site at the top. Color intensity indicates the magnitude of the correlation, with dark blue indicating a strong positive correlation $(r=1)$ and dark red indicating a strong negative correlation $(r=-1)$. More negative SPEI values are indicative of droughty conditions while more positive SPEI values are indicative of non-droughty conditions. So, a positive correlation between growth and SPEI (blue squares) corresponds to more growth during less droughty conditions while a negative correlation between growth and SPEI (red squares) corresponds to less growth during non-droughty conditions (or more growth during droughty conditions). Correlations are based on data collected in 2016 on the Tripod Fire in the Okanogan-Wenatchee National Forest, Washington, USA. Figure S3. B. Correlation coefficients (Pearson's) between lodgepole pine annual growth at each site and mean temperature for months prior to the year of growth (July to December) and through the growing season (January to September). To ensure adequate sampling depth, only 14 sites were considered in this analysis, and they are ordered with the lowest elevation site on the bottom of the matrix and the highest elevation site at the top. Color intensity indicates the magnitude of the correlation, with dark blue indicating a strong positive correlation $(r=1)$ and dark red indicating a strong negative correlation $(r=-1)$. A positive correlation between growth and temperature (blue squares) corresponds to more growth during warmer conditions while a negative correlation between growth and temperature (red squares) corresponds to less growth during warmer conditions (or more growth during cooler conditions). Correlations are based on data collected in 2016 on the Tripod Fire in the OkanoganWenatchee National Forest, Washington, USA. Figure S3. C. Correlation coefficients (Pearson's) between lodgepole pine annual growth at each site and total precipitation values for months prior to the year of growth (July to December) and through the growing season (January to September). To ensure adequate sampling depth, only 14 sites were considered in this analysis, and they are ordered with the lowest elevation site on the bottom of the matrix and the highest elevation site at the top. Color intensity indicates the magnitude of the correlation, with dark blue indicating a strong positive correlation $(r=1)$ and dark red indicating a strong negative correlation $(r=-1)$. A positive correlation between growth and precipitation (blue squares) corresponds to more growth during periods with more rain while a negative correlation between growth and precipitation (red squares) corresponds to less growth during periods with more rain (or more growth during periods with less rain). Correlations are based on data collected in 2016 on the Tripod Fire in the Okanogan-Wenatchee National Forest, Washington, USA. (PDF 224 kb)

\section{Acknowledgements}

I thank D.L. Peterson, B.J. Harvey, S. Prichard, D. McKenzie, J. Lawler, and A. Cansler for their advice throughout this project and constructive feedback on this manuscript, as well as E. Bott, A. Juang, and S. Steinly for their tireless help in the field. This project was possible thanks to support from the Wilderness Society's Gloria Barron Scholarship, the Northwest Scientific Association, and the University of Washington's Doris Duke Conservation Scholars Program.

\section{Author's contributions}

CEL designed and carried out this research and wrote the manuscript. The author read and approved the final manuscript.

\section{Funding}

A Gloria Barron Scholarship from The Wilderness Society as well as a student grant from the Northwest Scientific Association supported field work. The University of Washington's Doris Duke Conservation Scholars Program supported three field assistants.

\section{Availability of data and materials}

Data and scripts are available at https://github.com/CaitLittlef/Tripod

\section{Ethics approval and consent to participate}

Not applicable.

\section{Consent for publication}

Not applicable.

\section{Competing interests}

The author declares that she has no competing interests.

Received: 9 January 2019 Accepted: 17 June 2019

Published online: 04 October 2019

\section{References}

Abatzoglou, J.T., D.J. McEvoy, and K.T. Redmond. 2017. The West Wide Drought Tracker: drought monitoring at fine spatial scales. Bulletin of the American Meteorological Society 98: 1815-1820 https://doi.org/10.1175/BAMS-D-160193.1.

Abatzoglou, J.T., D.E. Rupp, and P.W. Mote. 2014. Seasonal climate variability and change in the Pacific Northwest of the United States. Journal of Climate 27: 2125-2142 https://doi.org/10.1175/JCLI-D-13-00218.1.

Agee, J.K. 1993. Fire ecology of Pacific Northwest forests. Washington, D.C. Island Press.

Aho, K., D. Derryberry, and T. Peterson. 2014. Model selection for ecologists: the worldviews of AIC and BIC. Ecology 95 (3): 631-636 https://doi.org/10.1890/ 13-1452.1. 
Akaike, H. 1973. Information theory and an extension of the maximum likelihood principle. In Proceedings of the second international symposium on information theory, ed. by B.N. Petrov and S. Caski, 267-281. Budapest: Akademiai Kaido.

Andrus, R.A., B.J. Harvey, K.C. Rodman, S.J. Hart, and T.T. Veblen. 2018. Moisture availability limits subalpine tree establishment. Ecology 99: 567-575 https:// doi.org/10.1002/ecy.2134.

Bell, D.M., J.B. Bradford, and W.K. Lauenroth. 2014. Early indicators of change: divergent climate envelopes between tree life stages imply range shifts in the western United States. Global Ecology and Biogeography 23: 168-180 https://doi.org/10.1111/geb.12109.

Brown, P.M. 2006. Climate effects on fire regimes and tree recruitment in Black Hills ponderosa pine forests. Ecology 87: 2500-2510 https://doi.org/10.1890/ 0012-9658(2006)87[2500:CEOFRA]2.0.CO;2.

Brubaker, L.B. 1980. Spatial patterns of tree growth anomalies in the Pacific Northwest. Ecology 61: 798-807 https://doi.org/10.2307/1936750.

Bunn, A., M. Korpela, F. Biondi, F. Campelo, P. Mérian, F. Qeadan, C. Zang, D. Pucha-Cofrep, and J. Wernicke. 2018. dpIR: dendrochronology program library in R. R package version 1.6.7. https://CRAN.R-project.org/package=dpIR Accessed 19 Oct 2018.

Bunn, A.G. 2010. Statistical and visual crossdating in R using the dpIR library. Dendrochronologia 28: 251-258 https://doi.org/10.1016/j.dendro.2009.12.001.

Burns, R.M., and B.H. Honkala, technical coordinators. 1990. Silvics of North America. Volume 1, conifers. Agriculture Handbook 654. Washington D.C. USDA Forest Service.

Cansler, C.A., and D. McKenzie. 2012. How robust are burn severity indices when applied in a new region? Evaluation of alternate field-based and remotesensing methods. Remote Sensing 4: 456-483 https://doi.org/10.3390/ rs4020456.

Cansler, C.A., and D. McKenzie. 2014. Climate, fire size, and biophysical setting control fire severity and spatial pattern in the northern Cascade Range, USA Ecological Applications 24 (5): 1037-1056 https://doi.org/10.1890/13-1077.1.

Cansler, C.A., D. McKenzie, and C.B. Halpern. 2018. Fire enhances the complexity of forest structure in alpine treeline ecotones. Ecosphere 9: e02091 https:// doi.org/10.1002/ecs2.2091.

Case, M.J., and D.L. Peterson. 2005. Fine-scale variability in growth-climate relationships of Douglas-fir, North Cascade Range, Washington. Canadian Journal of Forest Research 35: 2743-2755 https://doi.org/10.1139/x05-191.

Claveau, Y., C. Messier, P.G. Comeau, and K.D. Coates. 2002. Growth and crown morphological responses of boreal conifer seedlings and saplings with contrasting shade tolerance to a gradient of light and height. Canadian Journal of Forest Research 32: 458-468 https://doi.org/10.1139/x01-220.

Cook, B.I., A.P. Williams, J.S. Mankin, R. Seager, J.E. Smerdon, and D. Singh. 2018. Revisiting the leading drivers of Pacific coastal drought vulnerability in the contiguous United States. Journal of Climate 31: 25-43 https://doi.org/10. 1175/JCLI-D-17-0172.1.

Cook, R.D. 1977. Detection of influential observation in linear regression. Technometrics 19 (1): 15-18 https://doi.org/10.1080/00401706.1977.10489493.

D'Amato, A.W., J.B. Bradford, S. Fraver, and B.J. Palik. 2013. Effects of thinning on drought vulnerability and climate response in north temperate forest ecosystems. Ecological Applications 23: 1735-1742 https://doi.org/10.1890/13-0677.1.

D'Odorico, P., L. Ridolfi, A. Porporato, and I. Rodriguez-Iturbe. 2000. Preferential states of seasonal soil moisture: the impact of climate fluctuations. Water Resources Research 36 (8): 2209-2219 https://doi.org/10.1029/2000WR900103.

Davis, K.T., S.Z. Dobrowski, P.E. Hiquera, Z.A. Holden, T.T. Veblen, M.T. Rother, S.A. Parks, A. Sala, and M.P. Maneta. 2019. Wildfires and climate change push low-elevation forests across a critical climate threshold for tree regeneration. Proceedings of the National Academy of Sciences of the United States of America 116 (13): 6193-6198 https://doi.org/10.1073/ pnas.1815107116.

Davis, M.B., and R.G. Shaw. 2001. Range shifts and adaptive responses to quaternary climate change. Science 292: 673-679 https://doi.org/10.1126/ science. 292.5517 .673

Dobrowski, S.Z., A.K. Swanson, J.T. Abatzoglou, Z.A. Holden, H.D. Safford, M.K. Schwartz, and D.G. Gavin. 2015. Forest structure and species traits mediate projected recruitment declines in western US tree species. Global Ecology and Biogeography 24: 917-927 https://doi.org/10.1111/geb.12302.

Dobson, A.J., and A.G. Barnett. 2008. An introduction to generalized linear models. Third edition. Boca Raton: Taylor and Francis Group.

Dodson, E.K., and H.T. Root. 2013. Conifer regeneration following standreplacing wildfire varies along an elevation gradient in a ponderosa pine forest, Oregon, USA. Forest Ecology and Management 302: 163-170 https://doi.org/10.1016/j.foreco.2013.03.050

Donato, D.C., J.B. Fontaine, J.L. Campbell, W.D. Robinson, J.B. Kauffman, and B.E. Law. 2009. Conifer regeneration in stand-replacement portions of a large mixed-severity wildfire in the Klamath-Siskiyou Mountains. Canadian Journal of Forest Research 39: 823-838 https://doi.org/10.1139/X09-016.

Donato, D.C., B.J. Harvey, and M.G. Turner. 2016. Regeneration of montane forests 24 years after the 1988 Yellowstone fires: a fire-catalyzed shift in lower treelines? Ecosphere 7: e01410 https://doi.org/10.1002/ecs2.1410.

Dormann, C.F., J.M. McPherson, M.B. Araújo, R. Bivand, J. Bolliger, G. Carl, R.G. Davies, A. Hirzel, W. Jetz, W.D. Kissling, I. Kühn, R. Ohlemuller, P.R. Peres-Neto, B. Reineking, B. Schröder, F.M. Schurr, and R. Wilson. 2007. Methods to account for spatial autocorrelation in the analysis of species distributional data: a review. Ecography 30 (5): 609-628 https://doi.org/10.1111/j.2007.0906-7590.05171.x.

Dunn, OJ. 1961. Multiple comparisons among means. Journal of the American Statistical Association 56 (293): 52-64 https://doi.org/10.1080/01621459.1961.10482090.

Eidenshink, J., B. Schwind, K. Brewer, Z. Zhu, B. Quayle, and S. Howard. 2007. A project for monitoring trends in fire severity. Fire Ecology 3 (1): 3-21 https:// doi.org/10.4996/fireecology.0301003.

ESRI [Environmental Systems Research Institute]. 2014. ArcGIS Release 10.3. Redlands: ESRI.

Evans, J.S., J. Oaklaf, S.A. Cushman, and D. Theobald. 2014. An ArcGIS toolbox for surface gradient and geomorphometric modeling, v2.0. http://evansmurphy. wix.com/evansspatial Accessed 23 Jan 2016.

Fawcett, T. 2006. An introduction to ROC analysis. Pattern Recognition Letters 27 (8): 861-874 https://doi.org/10.1016/j.patrec.2005.10.010.

Fortin, M.J., and M.R. Dale. 2005. Spatial analysis: a guide for ecologists. Cambridge: Cambridge University Press.

Geiger, R., R.H. Aron, and P. Todhunter. 2009. The climate near the ground. Seventh edition. Lanham: Rowman and Littlefield Publishers, Inc.

Germino, M.J., W.K. Smith, and A.C. Resor. 2002. Conifer seedling distribution and survival in an alpine-treeline ecotone. Plant Ecology 162: 157-168 https://doi. org/10.1023/A:1020385320738.

Gessler, P.E., I.D. Moore, N.J. McKenzie, and P.J. Ryan. 1995. Soil-landscape modeling and spatial prediction of soil attributes. International Journal of Geographical Information Systems 9: 421-432 https://doi.org/10.1080/ 02693799508902047.

Gill, N.S., D. Jarvis, T.T. Veblen, S.T.A. Pickett, and D. Kulakowski. 2017. Is initial post-disturbance regeneration indicative of longer-term trajectories? Ecosphere 8: e01924 https://doi.org/10.1002/ecs2.1924.

Gray, S.T., J.L. Betancourt, S.T. Jackson, and R.G. Eddy. 2006. Role of multidecadal climate variability in a range extension of pinyon pine. Ecology 87: $1124-$ 1130 https://doi.org/10.1890/0012-9658(2006)87[1124:ROMCVI]2.0.CO;2.

Gray, S.T., C.L. Fastie, S.T. Jackson, and J.L. Betancourt. 2004. Tree-ring-based reconstruction of precipitation in the Bighorn Basin, Wyoming, since 1260. Journal of Climate 17: 3855-3865 https://doi.org/10.1175/15200442(2004)017\%3C3855:TROPIT\%3E2.0.CO;2.

Grubb, P.J. 1977. The maintenance of species richness in plant communities: the importance of the regeneration niche. Biological Review 52: 107-145 https:// doi.org/10.1111/j.1469-185X.1977.tb01347.X.

Haffey, C., T.D. Sisk, C.D. Allen, A.E. Thode, and E.Q. Margolis. 2018. Limits to ponderosa pine regeneration following large high-severity forest fires in the United States Southwest. Fire Ecology 14: 143-163. https://doi.org/10.4996/ fireecology.140114316

Hankin, L.E., P.E. Higuera, K.T. Davis, and S.Z. Dobrowski. 2018. Accuracy of node and bud-scar counts for aging two dominant conifers in western North America. Forest Ecology and Management 427: 365-371 https://doi. org/10.1016/j.foreco.2018.06.001.

Harpold, A.A., and N.P. Molotch. 2015. Sensitivity of soil water availability to changing snowmelt timing in the western US. Geophysical Research Letters 42 (19): 8011-8020 https://doi.org/10.1002/2015GL065855.

Harvey, B.J., D.C. Donato, and M.G. Turner. 2016. High and dry: post-fire tree seedling establishment in subalpine forests decreases with post-fire drought and large stand-replacing burn patches. Global Ecology and Biogeography 25: 655-669 https://doi.org/10.1111/geb.12443.

Harvey, B.J., and B.A. Holzman. 2014. Divergent successional pathways of stand development following fire in a California closed-cone pine forest. Journal of Vegetation Science 25: 88-99 https://doi.org/10.1111/jvs.12073.

Hessburg, P.F., J.K. Agee, and J.F. Franklin. 2005. Dry forests and wildland fires of the inland northwest USA: contrasting the landscape ecology of the pre-settlement and modern eras. Forest Ecology and Management 211: 117-139 https://doi.org/10.1016/j.foreco.2005.02.016. 
Hessburg, P.F., D.J. Churchill, A.J. Larson, R.D. Haugo, C. Miller, T.A. Spies, M.P. North, N.A. Povak, R.T. Belote, P.H. Singleton, W.L. Gaines, R.E. Keane, G.H. Aplet, S.L. Stephens, P. Morgan, P.A. Bisson, B.E. Rieman, R.B. Salter, and G.H. Reeves. 2015. Restoring fire-prone Inland Pacific landscapes: seven core principles. Landscape Ecology 30: 1805-1835 https://doi.org/10.1007/s10980-015-0218-0.

Hosmer, D.W., and S. Lemeshow. 1980. Goodness of fit tests for the multiple logistic regression model. Communications in Statistics-Theory and Methods 9 (10): 1043-1069 https://doi.org/10.1080/03610928008827941.

$\mathrm{Hu}$, J., D.J.P. Moore, S.P. Burns, and R.K. Monson. 2010. Longer growing seasons lead to less carbon sequestration by a subalpine forest. Global Change Biology 16: 771-783 https://doi.org/10.1111/j.1365-2486.2009.01967.x.

Jackman, S. 2017. pscl: classes and methods for R developed in the political science computational laboratory. R package version 1.5.2. https://CRAN. R-project.org/package=pscl Accessed 7 Dec 2017

Jackson, S.T., J.L. Betancourt, R.K. Booth, and S.T. Gray. 2009. Ecology and the ratchet of events: climate variability, niche dimensions, and species distributions. Proceedings of the National Academy of Sciences of the United States of America 106: 19685-19692 https://doi.org/10.1073/pnas. 0901644106

Jenness, J., B. Brost, and P. Beier. 2013. Land Facet Corridor Designer, v 1.0. http:// www.jennessent.com/arcgis/land_facets.htm Accessed 23 Jan 2016

Johnstone, J.F., C.D. Allen, J.F. Franklin, L.E. Frelich, B.J. Harvey, P.E. Higuera, M.C. Mack, R.K. Meentemeyer, M.R. Metz, G.L.W. Perry, T. Schoennagel, and M.G. Turner. 2016. Changing disturbance regimes, ecological memory, and forest resilience. Frontiers in Ecology and the Environment 14: 369-378 https://doi.org/10.1002/fee.1311.

Kashian, D.M., M.G. Turner, W.H. Romme, and C.G. Lorimer. 2005. Variability and convergence in stand structural development on a fire-dominated subalpine landscape. Ecology 86: 643-654 https://doi.org/10.1890/03-0828.

Kemp, K.B., P.E. Higuera, and P. Morgan. 2016. Fire legacies impact conifer regeneration across environmental gradients in the US northern Rockies. Landscape Ecology 31: 619-636 https://doi.org/10.1007/s10980015-0268-3.

Kemp, K.B., P.E. Higuera, P. Morgan, and J.T. Abatzoglou. 2019. Climate will increasingly determine post-fire tree regeneration success in low-elevation forests, northern Rockies, USA. Ecosphere 10: e02568 https://doi.org/10.1002/ecs2.2568.

Kolden, C.A., J.T. Abatzoglou, J.A. Lutz, C.A. Cansler, J.T. Kane, J.W. van Wagtendonk, and C.H. Key. 2015. Climate contributors to forest mosaics: ecological persistence following wildfire. Northwest Science 89: 219-239 https://doi.org/10.3955/046.089.0305.

Kotze, D.J., R.B. O'Hara, and S. Lehvävirta. 2012. Dealing with varying detection probability, unequal sample sizes and clumped distributions in count data. PLOS ONE 7 (7): e40923 https://doi.org/10.1371/journal.pone.0040923.

Kozlowski, T.T., and S.G. Pallardy. 1997. Growth control in woody plants. San Diego: Academic Press.

Kozlowski, T.T., and S.G. Pallardy. 2002. Acclimation and adaptive responses of woody plants to environmental stresses. The Botanical Review 68: 270-334 https://doi.org/10.1663/0006-8101(2002)068[0270:AAAROW]2.0.CO;2.

Krannitz, P.G., and T.E. Duralia. 2004. Cone and seed production in Pinus ponderosa: a review. Western North American Naturalist 64: 208-218.

Krawchuk, M.A., S.L. Haire, J. Coop, M.-A. Parisien, E. Whitman, G. Chong, and C. Miller. 2016. Topographic and fire weather controls of fire refugia in forested ecosystems of northwestern North America. Ecosphere 7: e01632. https://doi.org/10.1002/ecs2.1632

Kruskal, W.H., and W.A. Wallis. 1952. Use of ranks in one-criterion variance analysis. Journal of the American Statistical Association 47: 583-621 (and errata, ibid. 48: 907-911). https://doi.org/10.1080/01621459.1952.10483441.

Larson, A.J., R.T. Belote, C.A. Cansler, S.A. Parks, and M.S. Dietz. 2013. Latent resilience in ponderosa pine forest: effects of resumed frequent fire. Ecological Applications 23: 515-522 https://doi.org/10.1890/13-0066.1.

Lewis, F., A. Butler, and L. Gilbert. 2011. A unified approach to model selection using the likelihood ratio test. Methods in Ecology and Evolution 2 (2): 155-162 https://doi.org/10.1111/j.2041-210X.2010.00063.x.

Litton, C.M., M.G. Ryan, D.B. Tinker, and D.H. Knight. 2003. Belowground and aboveground biomass in young postfire lodgepole pine forests of contrasting tree density. Canadian Journal of Forest Research 33: 351$363 \mathrm{https}: / /$ doi.org/10.1139/×02-181.

Lyons-Tinsley, C.M., and D.L. Peterson. 2012. Surface fuel treatments in young, regenerating stands affect wildfire severity in a mixed conifer forest, eastside Cascade Range, Washington, USA. Forest Ecology and Management 270: 117-125 https://doi.org/10.1016/j.foreco.2011.04.016.
Martin, T.G., B.A. Wintle, J.R. Rhodes, P.M. Kuhnert, S.A. Field, S.J. Low-Choy, A.J. Tyre, and H.P. Possingham. 2005. Zero tolerance ecology: improving ecological inference by modelling the source of zero observations. Ecology Letters 8 (11): 1235-1246 https://doi.org/10.1111/j. 1461-0248.2005.00826.x.

McCune, B., and D. Keon. 2002. Equations for potential annual direct incident radiation and heat load. Journal of Vegetation Science 13: 603-606 https://doi. org/10.1111/j.1654-1103.2002.tb02087.x.

McDowell, N., W.T. Pockman, C.D. Allen, D.D. Breshears, N. Cobb, T. Kolb, J. Plaut, J. Sperry, A. West, D.G. Williams, and E.A. Yepez. 2008. Mechanisms of plant survival and mortality during drought: why do some plants survive while others succumb to drought? New Phytologist 178: 719-739 https://doi.org/10. $1111 /$ j.1469-8137.2008.02436.x.

McGarigal, K., S. Cushman, and S. Stafford. 2000. Multivariate statistics for wildlife and ecology research. New York: SpringerVerlag https://doi.org/10.1007/978-14612-1288-1.

McKenzie, D., D.W. Peterson, D.L. Peterson, and P.E. Thornton. 2003. Climatic and biophysical controls on conifer species distributions in mountain forests of Washington State, USA. Journal of Biogeography 30: 1093-1108 https://doi. org/10.1046/j.1365-2699.2003.00921.x.

Merkle, E., D. You, L. Schneider, and S. Bae. 2018. nonnest2: tests of non-nested models. R package. R package version 0.5-2. https://CRAN.R-project.org/ package=nonnest2 Accessed 1 Mar 2019.

Millar, C.I, and N.L. Stephenson. 2015. Temperate forest health in an era of emerging megadisturbance. Science 349: 823-826 https://doi.org/10.1126/science.aaa9933.

Misson, L., A. Gershenson, J. Tang, M. McKay, W. Cheng, and A. Goldstein. 2006. Influences of canopy photosynthesis and summer rain pulses on root dynamics and soil respiration in a young ponderosa pine forest. Tree Physiology 26: 833-844 https://doi.org/10.1093/treephys/26.7.833.

Morelli, T.L., C. Daly, S.Z. Dobrowski, D.M. Dulen, J.L. Ebersole, S.T. Jackson, J.D. Lundquist, C.I. Millar, S.P. Maher, W.B. Monahan, K.R. Nydick, K.T. Redmond, S. C. Sawyer, S. Stock, and S.R. Beissinger. 2016. Managing climate change refugia for climate adaptation. PLOS ONE 11: e0159909 https://doi.org/10. 1371/journal.pone.0159909.

Paradis, E. 2018. ape: analyses of phylogenetics and evolution in R language. $R$ package version 5.1. https://CRAN.R-project.org/package=ape Accessed 19 May 2018.

Pataki, D.E., R. Oren, and W.K. Smith. 2000. Sap flux of co-occurring species in a Western subalpine forest during seasonal soil drought. Ecology 81: 2557-2566 https://doi.org/10.1890/0012-9658(2000)081[2557:SFOCOS]2.0.CO;2.

Paul, P., M.L. Pennell, and S. Lemeshow. 2013. Standardizing the power of the Hosmer-Lemeshow goodness of fit test in large data sets. Statistics in Medicine 32 (1): 67-80 https://doi.org/10.1002/sim.5525.

Pearson, K, and H.O.M.F. Erdmann. 1896. VII. Mathematical contributions to the theory of evolution.- - III. Regression, heredity, and panmixia. Philosophical Transactions of the Royal Society of London. Series A, Containing Papers of a Mathematical or Physical Character (187): 253-318 https://doi.org/10.1098/rsta.1896.0007.

Pebesma, E., and B. Gräler. 2018. gstat: spatial and spatio-temporal geostatistical modeling, prediction, and simulation. R package version 1.1.6. https://CRAN. R-project.org/package=gstat Accessed 5 May 2018.

Peterson, D.W., and D.L. Peterson. 2001. Mountain hemlock growth responds to climatic variability at annual and decadal time scales. Ecology 82: 3330-3345 https://doi.org/10.1890/0012-9658(2001)082[3330:MHGRTC]2.0.CO;2.

Prichard, S.J., and M.C. Kennedy. 2014. Fuel treatments and landform modify landscape patterns of burn severity in an extreme fire event. Ecological Applications 24: 571-590 https://doi.org/10.1890/13-0343.1.

Prichard, S.J., C.S. Stevens-Rumann, and P.F. Hessburg. 2017. Shifting global fire regimes: lessons from reburns and research needs. Forest Ecology and Management 396: 217-233 https://doi.org/10.1016/j.foreco.2017.03.035.

R Core Team. 2017. R: a language and environment for statistical computing. Vienna: R Foundation for Statistical Computing http://www.R-project.org/

Redmond, M.D., N.S. Cobb, M.J. Clifford, and N.N. Barger. 2015. Woodland recovery following drought-induced tree mortality across an environmental stress gradient. Global Change Biology 21: 3685-3695 https:/doi.org/10.1111/gcb.12976.

Reilly, MJ., C.. Dunn, G.W. Meigs, T.A. Spies, R.E. Kennedy, J.D. Bailey, and K. Briggs. 2017. Contemporary patterns of fire extent and severity in forests of the Pacific Northwest, USA (1985-2010). Ecosphere 8: e01695 https://doi.org/10.1002/ecs2.1695.

Restaino, C.M., D.L. Peterson, and J. Littell. 2016. Increased water deficit decreases Douglas-fir growth throughout western US forests. Proceedings of the National Academy of Sciences of the United States of America 113: 9557-9562 https://doi.org/10.1073/pnas.1602384113. 
Reyer, C.P.O., N. Brouwers, A. Rammig, B.W. Brook, J. Epila, R.F. Grant, M. Holmgren, F. Langerwisch, S. Leuzinger, W. Lucht, B. Medlyn, M. Pfeifer, J. Steinkamp, M.C. Vanderwel, H. Verbeeck, and D.M. Villela. 2015. Forest resilience and tipping points at different spatio-temporal scales: approaches and challenges. Journal of Ecology 103: 5-15 https://doi.org/10.1111/1365-2745.12337.

Ripley, B., W. Venables, D.M. Bates, K. Hornik, A. Gebhardt, and D. Firth. 2019 Modern applied statistics with S. R package version 7.3.5. https://cran.rproject.org/package=MASS Accessed 5 June 2019.

Romme, W.H., T.G. Whitby, D.B. Tinker, and M.G. Turner. 2016. Deterministic and stochastic processes lead to divergence in plant communities 25 years after the 1988 Yellowstone fires. Ecological Monographs 86: 327-351 https://doi. org/10.1002/ecm.1220.

Rother, M., and T. Veblen. 2017. Climate drives episodic conifer establishment after fire in dry ponderosa pine forests of the Colorado Front Range, USA. Forests 8: 159 https://doi.org/10.3390/f8050159.

Seidel, K.W., and P.H. Cochran. 1981. Silviculture of mixed conifer forests in eastern Oregon and Washington. USDA Forest Service General Technical Report PNW-GTR-121. Portland: USDA Forest Service, Pacific Northwest Research Station https://doi.org/10.2737/PNW-GTR-121.

Seidl, R., T.A. Spies, D.L. Peterson, S.L. Stephens, and J.A. Hicke. 2016. Searching for resilience: addressing the impacts of changing disturbance regimes on forest ecosystem services. Journal of Applied Ecology 53: 120-129 https://doi.org/10. $1111 / 1365-2664.12511$

Spearman, C. 1904. The proof and measurement of association between two things. American Journal of Psychology 15: 72-101 https://doi.org/10.2307/1412159.

Stephenson, N.L. 1998. Actual evapotranspiration and deficit: biologically meaningful correlates of vegetation distribution across spatial scales. Journal of Biogeography 25: 855-870 https://doi.org/10.1046/j.1365-2699.1998.00233.x.

Stevens-Rumann, C.S., K.B. Kemp, P.E. Higuera, B.J. Harvey, M.T. Rother, D.C. Donato, P. Morgan, and T.T. Veblen. 2018. Evidence for declining forest resilience to wildfires under climate change. Ecology Letters 21: 243-252 https://doi.org/10.1111/ele.12889.

Subhash, R.L, J.L. Keim, and P. Solymos. 2019. ResourceSelection: resource selection (probability) functions for use-availability data. R package version 0.3-0. https:// CRAN.R-project.org/package=ResourceSelection Accessed 2 Mar 2019.

Tepley, A.J., J.R. Thompson, H.E. Epstein, and K.J. Anderson-Teixeira. 2017. Vulnerability to forest loss through altered postfire recovery dynamics in a warming climate in the Klamath Mountains. Global Change Biology 23: 41174132 https://doi.org/10.1111/gcb.13704.

Teste, F.P., S.W. Simard, D.M. Durall, R.D. Guy, M.D. Jones, and A.L. Schoonmaker. 2009. Access to mycorrhizal networks and roots of trees: importance for seedling survival and resource transfer. Ecology 90: 2808-2822 https://doi. org/10.1890/08-1884.1.

Tinker, D.B., W.H. Romme, W.W. Hargrove, R.H. Gardner, and M.G. Turner. 1994. Landscape-scale heterogeneity in lodgepole pine serotiny. Canadian Journal of Forest Research 24: 897-903 https://doi.org/10.1139/x94-118.

Turner, M.G., W.H. Romme, and R.H. Gardner. 1999. Prefire heterogeneity, fire severity, and early postfire plant reestablishment in subalpine forests of Yellowstone National Park, Wyoming. International Journal of Wildland Fire 9: 21-36 https://doi.org/10.1071/WF99003.

Urza, A., and J. Sibold. 2013. Nondestructive aging of postfire seedlings for four conifer species in northwestern Montana. Western Journal of Applied Forestry 28: 22-29 https://doi.org/10.5849/wjaf.11-014

Urza, A.K., and J.S. Sibold. 2017. Climate and seed availability initiate alternate post-fire trajectories in a lower subalpine forest. Journal of Vegetation Science 28: 43-56 https://doi.org/10.1111/jvs.12465.

USGCRP [United States Global Change Research Program]. 2018. In Impacts, risks, and adaptation in the United States: fourth national climate assessment, volume II: report-in-brief, ed. D.R. Reidmiller, C.W. Avery, D.R. Easterling, K.E. Kunkel, K.L.M. Lewis, T.K. Maycock, and B.C. Stewart. Washington, D.C., US Government Publishing Office.

Vicente-Serrano, S.M., S. Beguería, and J.I. López-Moreno. 2010. A multiscalar drought index sensitive to global warming: the Standardized Precipitation Evapotranspiration Index. Journal of Climate 23: 1696-1718 https://doi.org/10. 1175/2009JCLI2909.1.

von Arx, G., E. Graf Pannatier, A. Thimonier, and M. Rebetez. 2013. Microclimate in forests with varying leaf area index and soil moisture: potential implications for seedling establishment in a changing climate. Journal of Ecology 101: 1201-1213 https://doi.org/10.1111/1365-2745.12121.
Vuong, Q.H. 1989. Likelihood ratio tests for model selection and non-nested hypotheses. Econometrica: Journal of the Econometric Society 57: 307-333 https://doi.org/10.2307/1912557.

Walck, J.L., S.N. Hidayati, K.W. Dixon, K.E.N. Thompson, and P. Poschlod. 2011. Climate change and plant regeneration from seed. Global Change Biology 17: 2145-2161 https://doi.org/10.1111/j.1365-2486.2010.02368.x.

Walther, G.-R., E. Post, P. Convey, A. Menzel, C. Parmesan, T.J.C. Beebee, J.-M. Fromentin, O. Hoegh-Guldberg, and F. Bairlein. 2002. Ecological responses to recent climate change. Nature 416: 389-395 https://doi.org/10.1038/416389a.

Wiens, J.A. 1989. Spatial scaling in ecology. Functional Ecology 3: 385-397 https:// doi.org/10.2307/2389612.

Woodward, A., E.G. Schreiner, and D.G. Silsbee. 1995. Climate, geography, and tree establishment in subalpine meadows of the Olympic Mountains, Washington, USA. Arctic, Antarctic, and Alpine Research 27: 217-225 https:// doi.org/10.2307/1551952

Xavier, R., N. Turck, A. Hainard, N. Tiberti, F. Lisacek, J.-C. Sanchez, and M. Müller. 2011 pROC: an open-source package for $\mathrm{R}$ and $\mathrm{S}+$ to analyze and compare ROC curves. BMB Bioinformatics 12: 77 https://doi.org/10.1186/1471-2105-12-77.

Young, D.J., C.M. Werner, K.R. Welch, T.P. Young, H.D. Safford, and A.M. Latimer. 2019. Post-fire forest regeneration shows limited climate tracking and potential for drought-induced type conversion. Ecology 100: e02571 https:// doi.org/10.1002/ecy.2571.

Zeileis, A., and T. Hothorn. 2002. Imtest: diagnostic checking in regression relationships. R package version 0.9-36 https://cran.r-project.org/web/ packages/Imtest Accessed 28 Feb 2019.

Zuur, A.F., I.E. leno, N.J. Walker, A.A. Savaliev, and G.M. Smith. 2009. Mixed effect models and extensions in ecology with R. Berlin: Springer.

\section{Publisher's Note}

Springer Nature remains neutral with regard to jurisdictional claims in published maps and institutional affiliations.

\section{Submit your manuscript to a SpringerOpen ${ }^{\circ}$ journal and benefit from:}

- Convenient online submission

- Rigorous peer review

- Open access: articles freely available online

High visibility within the field

- Retaining the copyright to your article

Submit your next manuscript at $\boldsymbol{\nabla}$ springeropen.com 